\title{
Exploratory comparisons between different anti-mitotics in clinically-used drug combination in triple negative breast cancer
}

This article has been corrected. Correction in Oncotarget. 2022; 13:1068-1068.

Bruna Cândido Guido', Douglas Cardoso Brandão ${ }^{1}$, Ana Luisa Augusto Barbosa ${ }^{1}$, Monique Jacob Xavier Vianna ${ }^{1}$, Lucas Faro ${ }^{1}$, Luciana Machado Ramos ${ }^{2}$, Fabíola Nihi $^{1}$, Márcio Botelho de Castro ${ }^{3}$, Brenno A.D. Neto ${ }^{4}$, José Raimundo Corrêa ${ }^{1}$ and Sônia Nair Báo ${ }^{1}$

\footnotetext{
${ }^{1}$ Microscopy and Microanalysis Laboratory, Department of Cell Biology, Institute of Biological Sciences, University of Brasília, Brasília 70910-900, Brazil

${ }^{2}$ Laboratory of Medicinal Chemistry and Organic Syntesis, Exact and Technological Sciences Campus, State University of Goiás, Anápolis, Goiás 75001-970, Brazil

${ }^{3}$ Veterinary Pathology Laboratory, Faculty of Agronomy and Veterinary Medicine, Department of Veterinary Medicine, University of Brasília, Brasília 70910-970, Brazil

${ }^{4}$ Laboratory of Medicinal and Technological Chemistry, University of Brasília, Chemistry Institute, University of Brasília, Brasília 70904-900, Brazil
}

Correspondence to: Sônia Nair Báo, email: snbao@unb.br

José Raimundo Corrêa, email: correa@unb.br

Keywords: KIF1 1 inhibition; Kinesin Eg5; breast cancer; adjuvant treatment; cancer progression

Received: April 13, $2021 \quad$ Accepted: August 13, $2021 \quad$ Published: September 14, 2021

Copyright: ( 2021 Guido et al. This is an open access article distributed under the terms of the Creative Commons Attribution License (CC BY 3.0), which permits unrestricted use, distribution, and reproduction in any medium, provided the original author and source are credited.

\section{ABSTRACT}

Triple-negative breast cancer (TNBC) constitutes a very aggressive type of breast cancer with few options of cytotoxic chemotherapy available for them. A chemotherapy regimen comprising of doxorubicin hydrochloride and cyclophosphamide, followed by paclitaxel, known as AC-T, is approved for usage as an adjuvant treatment for this type of breast cancer. In this study we aimed to elucidate the role of KIF11 in TNBC progression throughout its inhibition by two synthetic small molecules containing the DHPM core (dihydropyrimidin-2(1H)-ones or -thiones), with the hypothesis that these inhibitors could be an interesting option of antimitotic drug used alone or as adjuvant therapy in association with AC. For this purpose, we evaluated the efficacy of DHPMs used as monotherapy or in combination with doxorubicin and cyclophosphamide, in Balbc-nude mice bearing breast cancer induced by MDA-MB-231, having AC-T as positive control. Our data provide extensive evidence to demonstrate that KIF11 inhibitors showed pronounced antitumor activity, acting in key points of tumorigenesis and cancer progression in in vivo xenograft model of triple negative breast cancer, like down-regulation of KIF11 and ALDH1-A1. Moreover, they didn't show the classic peripheral neuropathy characterized by impaired mobility, as it is common with paclitaxel use. These results suggest that the use of a MAP inhibitor in breast cancer regimen treatment could be a promising strategy to keep antitumoral activity reducing the side effects.

\section{INTRODUCTION}

Triple-negative breast cancer (TNBC) constitutes a very aggressive subtype that accounts for approximately $12-18 \%$ of breast cancer patients $[1,2]$. The stratification of patients according to their receptor status is still a cost-effective, rapid and easy way to assess the suitability of breast cancer patients to targeted treatments [3]. Since TNBCs patients do not express estrogen receptor (ER), progesterone receptor (PR) and human epidermal growth factor receptor (HER-2), they are not eligible for hormone or HER2 target therapies, and so, few chemotherapy options remain available for them $[4,5]$. 
Chemotherapeutic agents currently approved for these breast tumors that are unsuitable for targeted therapies, typically target DNA synthesis and repair, therefore tending to have more side effects. In general, drug combinations commonly work better for TNBC patients than monotherapy because different drugs can achieve the heterogeneous cell mass throughout different pathways [6]. This treatment is usually given as a combination of drugs that associates DNA intercalators, that inhibit DNA and RNA synthesis, such as doxorubicin [7]; alkylating agents that irreversibly crosslink DNA leading to apoptosis, such as cyclophosphamide; and mitotic inhibitors, such as taxanes [3].

A chemotherapy regimen comprising of doxorubicin hydrochloride (Adriamycin) and cyclophosphamide, followed by paclitaxel (Taxol), known as AC-T, is approved for usage as an adjuvant treatment for breast cancer. Besides the great proportion of patients that relapse and evolve resistance, leading to poor overall survival, there are still severe issues related to side effects of these drugs resulting in a huge clinical need for the identification of effective targets in TNBC [8].

Paclitaxel is an antineoplastic agent indicated as first-line and subsequent therapy for the treatment of advanced carcinoma of ovarian, breast, lung and also for Kaposi's sarcoma [9, 10]. Its antineoplastic effect is due to its activity of hyper-stabilization of microtubules structures and by its direct interaction to $\beta$ tubulin as well [11]. The resulting complex abolishes cell's ability to use its cytoskeleton in a flexible way, inducing mitotic arrest and leading to cell death in a subset of the arrested population [12]. However, since this dynamic instability of microtubules of shortening and lengthening is essential for important cell functions besides cell division, like cargo transportations, many side effects come along with the administration of this drug [13]. Some of the most common adverse effects are low blood counts, both red and white cells, and platelets as well, what can increase the risk of infection, anemia and bleeding, arthralgias and myalgias, nausea, vomiting and severe peripheral neuropathy.

Microtubule-associated proteins (MAPs) have emerged as an alternative and promising anticancer target since their inhibition would block mitosis without producing neurotoxicity [14]. Some of these MAPs, like Kinesin Spindle Protein (KSP), also known as KIF11 or Kinesin Eg5, are not expressed in terminally differentiated cells, such as neurons; therefore, toxicities such as peripheral neuropathy are not predictable with KIF11 inhibitors. This class of proteins plays a specific and essential role in the assembly of the bipolar spindle and chromosome segregation through ATP hydrolysis. KIF11 inhibition leads to monoastral microtubule formation, which culminates in cell cycle arrest at mitosis and ultimately in cell death $[15,16]$. Besides its essential roles, it was recently shown that KIF11 overexpression might contribute to tumorigenesis [17] and is associated with a poorer prognosis in a broad range of cancers, such as breast cancer [18], hepatocellular carcinoma [19], laryngeal squamous cell carcinoma [20], astrocytic neoplasm [21] and renal cell carcinoma [22] among others, being suggested as a potential prognostic biomarker. Additionally, overexpression of KIF11 in transgenic mice induced the development of several types of malignancies [23]. Considering the already mentioned correlation between high levels of KIF11 and worse prognostic in different cancer types, several inhibitors for this motor protein are currently being studied in clinical trials [17]. However, despite the great results obtained in preclinical studies using KIF11 inhibitors there are still some problems being faced in clinics, like the occurrence of neutropenia being the dose-limiting factor and the emergence of resistance. Thus, vast majority of inhibitors that went to clinical trials have failed to show efficacy mainly when used as monotherapy suggesting that new treatment strategies could be used to succed [17, 24, 25].

In this study we aimed to elucidate the role of KIF11 in TNBC progression throughout its inhibition by two DHPM (dihydropyrimidin-2(1H)-ones or -thiones) based synthetic small molecules, previously characterized by our research group [26, 27]. For this purpose, we evaluated the efficacy of DHPMs used as monotherapy and in combination with other drugs approved for breast cancer treatment, in balbc-nude mice bearing breast cancer induced by MDA-MB-231 cells inoculation. Treatment with DHPMs was able to impair the correct chromosome segregation during metaphase in tumor cells, leading them to death by apoptosis. We have also shown that there is a correlation between KIF11 expression levels and inhibition of tumor progression. We demonstrated that this class of DHPMs worked better when used as adjuvant therapy, presenting similar results of growth tumor inhibition when compared to those induced by paclitaxel treatment, besides to down-regulate KIF11 and ALDH1-A1 expression, effects not observed in paclitaxel treatment group. This effectiveness was achieved without the classic peripheral neuropathy presented by taxanes suggesting that the use of KIF11inhibitors as adjuvant therapy in invasive breast cancer treatment could be a promising strategy.

\section{RESULTS}

\section{KIF11 inhibitors didn't show any toxicity related to weight loss, motor capacity or systemic toxicity}

Animals of all experimental groups were monitored with regards to their weight, behavior and clinical aspects. Animals body weight were assessed prior the beginning of treatment and twice a week throughout the experiment period as an important indicator of toxicity.

When considering monotherapy treatment, it was observed a weight reduction upon treatment with $4 \mathrm{bt}$ and 
$4 \mathrm{bc}(80 \mathrm{mg} / \mathrm{Kg})$ and PTX $(20 \mathrm{mg} / \mathrm{Kg})$ at time point of 1 week after the beginning of treatment, however, after this time no significant weight change in all experimental groups was observed compared to the control healthy group (Figure 1A).

When drug combination was administered in animals, a pronounced decrease in weight was observed one week after application of doxorubicin associated to cyclophosphamide (AC) and, after a time, animals recovered (Figure 1B). Additionally, animals treated with AC showed loss of appetite and considerable reduction in their level of activity, and some animals died due to the high toxicity of the treatment. The animals that recovered were randomized into two experimental groups to follow up the therapeutic regimen with cycles of paclitaxel or KIF11 inhibitor (4bt), but the administration of either of these two drugs did not cause any further reduction in the animals' weight (Figure 1B).

Although paclitaxel used as adjuvant therapy did not cause an expressive weight loss in animals since its dose was lower than the used for monotherapy, $10 \mathrm{mg} /$ $\mathrm{Kg}$ and $20 \mathrm{mg} / \mathrm{Kg}$ respectively, significant behavioral changes were observed in both groups (Supplementary Videos 1 and 2). A few minutes after administration, animals showed reduced motor capacity, and dragged their hind legs to move around. Even with the administration of higher doses of 4bt compared to paclitaxel dose, $80 \mathrm{mg} / \mathrm{Kg}$ versus 10 or $20 \mathrm{mg} / \mathrm{Kg}$, respectively, no similar adverse effect was observed neither in the treatment with $4 \mathrm{bt}$ as monotherapy nor when it was used with drug combination (Supplementary Videos 3 and 4).

Additionally, a complete blood count (CBC) and biochemical profile to evaluate drug toxicity to critical organs, such as liver and kidneys, were performed. As already described on literature, paclitaxel caused a decrease in blood counts, red and white cells and platelets as well. Our results corroborate these already mentioned findings. Treatment with paclitaxel $(20 \mathrm{mg} / \mathrm{Kg})$ caused the most prominent reduction in hematocrit values, as can be seen in Table 1. Paclitaxel group also presented a reduced red cell count, although not statistically significant and this alteration was responsible for the decrease observed in hemoglobin values for this treatment group (Table 1). As expected, paclitaxel also caused a reduction in total white blood cells (WBC) compared to healthy control animals (2139.39 \pm 684.75 and 4447.26 \pm 1434.71 , respectively) (Supplementary Table 1). White blood cells also presented alterations upon treatment in some other experimental groups compared to healthy animals. We observed a considerable increase in absolute lymphocytes number in vehicle and 4 bt group, and a pronounced decrease in paclitaxel treated animals (Supplementary Table 1). The red cell distribution width (RDW) presented statistically significant increase upon treatment with paclitaxel and drug combinations AC-T and AC-4bt.

With regards to biochemical parameters, only Lactic Acid Dehydrogenase (LDH) showed significant changes among treated groups compared to control of healthy animals (Table 2). Paclitaxel and both drug combinations were the ones that caused more pronounced decrease in LDH levels compared to control (Table 2).

\section{4bt used as monotherapy holds tumor growth}

To evaluate antitumor efficacy of KIF11 inhibitors used as monotherapy, nude mice bearing breast tumor were administered intraperitoneally (i.p.) with different doses of $4 \mathrm{bt}$ and $4 \mathrm{bc}(50 \mathrm{mg} / \mathrm{kg}$ or $80 \mathrm{mg} / \mathrm{kg})$ or paclitaxel (20 $\mathrm{mg} / \mathrm{Kg}$ ), used as positive control for comparison. Tumor growth was monitored during all the treatment time. Figure $1 \mathrm{C}$ shows that $4 \mathrm{bt}$ presented a significant antiproliferative activity and at the highest concentration tested $(80 \mathrm{mg} / \mathrm{kg})$ it was able to inhibit tumor growth mainly until 2.5 weeks from the beginning of treatment when compared to vehicle control. Animals treated with 4bc inhibitor didn't show any considerable difference in tumor volume compared to untreated animals.

A combination of the two inhibitors $(25 \mathrm{mg} / \mathrm{Kg}$ of each) was also tested to evaluate any possible synergic antitumor effect, but no significant changes were observed (Figure 1C).

\section{$4 \mathrm{bt}$ inhibitor used as adjuvant therapy potentiates the suppressor effect of drug combination in breast tumor in vitro and in vivo}

Based on the results obtained in the monotherapy experiments, where $4 \mathrm{bt}$ presented an interesting antitumor and antiproliferative activity, we aimed to evaluate the efficacy of 4 bt used as an adjuvant therapy in combination with doxorubicin and cyclophosphamide (AC), a treatment regimen choice used in association with paclitaxel for invasive triple negative breast cancer. Our proposal was to verify the possibility of using KIF11 inhibitor in this treatment regimen in replacement for paclitaxel.

In order to address this goal, we performed an in vitro survival assay to assess if the association of paclitaxel or $4 \mathrm{bt}$ would potentiate antitumor effect of treatment in MDA-MB-231 cells. Cells treated with AC-only for 24 h showed $34.2 \% \pm 0.27$ of viability (Figure 1D). With the addition of paclitaxel or $4 \mathrm{bt}$, the viability decreased to $29.70 \% \pm 0.66$ and $27.70 \% \pm 0.84$, respectively. Based on these results we performed in vivo tests to evaluate if these drugs combination would have the same effectiveness in the presence of the tumor microenvironment.

In vivo experiments showed that $4 \mathrm{bt}$ had similar activity to paclitaxel when used in combination with doxorubicin and cyclophosphamide significantly decreasing the tumor volume (Figure $1 \mathrm{E}$ and $1 \mathrm{~F}$ ). Tumor sizes were considerably reduced mainly after 1.5 weeks of the beginning of treatment, when the adjuvant therapy was introduced.

As can be noticed, 4bt activity was comparable to the one obtained with paclitaxel treatment, however 
Table 1: Red blood cell analysis of Balb-c nude mice bearing breast tumor

\begin{tabular}{|c|c|c|c|c|c|c|c|}
\hline & $\begin{array}{l}\text { Red cells } \\
\left(10^{6} / \mathrm{mm}^{3}\right)\end{array}$ & $\begin{array}{c}\text { Hemoglobin } \\
(\mathrm{g} / \mathrm{dL})\end{array}$ & Hematocrit (\%) & $\operatorname{MCV}(f 1)$ & МCH (pg) & MCHC (g/dL) & RDW (\%) \\
\hline CTL Healthy & $9.48 \pm 0.65$ & $14.50 \pm 0.81$ & $49.26 \pm 2.73$ & $52.52 \pm 0.69$ & $15.46 \pm 0.22$ & $29.44 \pm 0.32$ & $19.15 \pm 0.67$ \\
\hline Vehicle & $9.90 \pm 0.31$ & $14.60 \pm 0.23$ & $51.09 \pm 1.62^{* *}$ & $51.58 \pm 0.43$ & $14.74 \pm 0.31$ & $28.57 \pm 0.60$ & $20.06 \pm 0.32$ \\
\hline $4 \mathrm{bt}(50 \mathrm{mg} / \mathrm{Kg})$ & $9.38 \pm 0.23$ & $14.23 \pm 0.4$ & $48.53 \pm 1.62$ & $51.75 \pm 0.88$ & $15.18 \pm 0.23$ & $29.32 \pm 0.45$ & $19.68 \pm 0.40$ \\
\hline $4 \mathrm{bc}(50 \mathrm{mg} / \mathrm{Kg})$ & $9.29 \pm 0.3$ & $14.07 \pm 0.51$ & $47.43 \pm 2.06^{* *}$ & $51.07 \pm 081^{*}$ & $15.13 \pm 0.4$ & $29.67 \pm 0.68$ & $19.65 \pm 0.56$ \\
\hline $4 \mathrm{bt}(80 \mathrm{mg} / \mathrm{Kg})$ & $8.97 \pm 0.34$ & $13.56 \pm 0.56$ & $45.13 \pm 1.83^{* * * *}$ & $50.30 \pm 0.16^{* * *}$ & $15.13 \pm 0.21$ & $30.03 \pm 0.37$ & $19.70 \pm 0.22$ \\
\hline $4 \mathrm{bc}(80 \mathrm{mg} / \mathrm{Kg})$ & $9.75 \pm 0.4$ & $14.57 \pm 0.56$ & $48.77 \pm 2.11$ & $50.04 \pm 0.68^{* * * * *}$ & $14.94 \pm 0.12$ & $29.88 \pm 0.47$ & $20.34 \pm 0.41$ \\
\hline $4 \mathrm{bt}+4 \mathrm{bc}(25 \mathrm{mg} / \mathrm{kg})$ & $9.57 \pm 0.62$ & $14.48 \pm 0.84$ & $49.23 \pm 2.63$ & $51.48 \pm 0.71$ & $15.14 \pm 0.29$ & $29.39 \pm 0.54$ & $20.00 \pm 0.89$ \\
\hline Paclitaxel $20 \mathrm{mg} / \mathrm{kg}$ & $8.15 \pm 0.08$ & $12.80 \pm 0.14^{*}$ & $42.56 \pm 0.62^{* * * *}$ & $52.23 \pm 0.42$ & $15.73 \pm 0.05$ & $30.07 \pm 0.12$ & $22.85 \pm 0.98^{* * * *}$ \\
\hline AC-T & $8.72 \pm 0.15$ & $13.42 \pm 0.28$ & $44.57 \pm 0.99^{* * * *}$ & $51.10 \pm 0.71$ & $15.40 \pm 0.18$ & $30.10 \pm 0.46$ & $21.22 \pm 0.13^{* *}$ \\
\hline AC-4bt & $9.23 \pm 0.49$ & $14.06 \pm 0.80$ & $46.94 \pm 2.35^{* * *}$ & $50.84 \pm 0.71^{*}$ & $15.24 \pm 0.10$ & $29.98 \pm 0.36$ & $21.46 \pm 0.36^{* * * *}$ \\
\hline
\end{tabular}

MCV: Mean corpuscular volume; MCH: Mean corpuscular hemoglobin; MCHC: mean corpuscular hemoglobin concentration; RDW: red cell distribution width. Data represent mean \pm SEM. ${ }^{*} p<0.05,{ }^{* *} p<0.01,{ }^{* * *} p<0.001,{ }^{* * * *} p<0.0001$ as compared to control group (CTL Healthy).

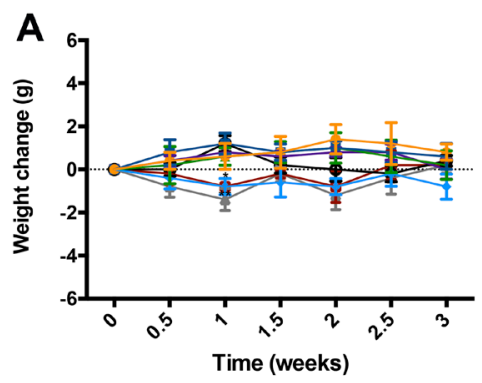

C

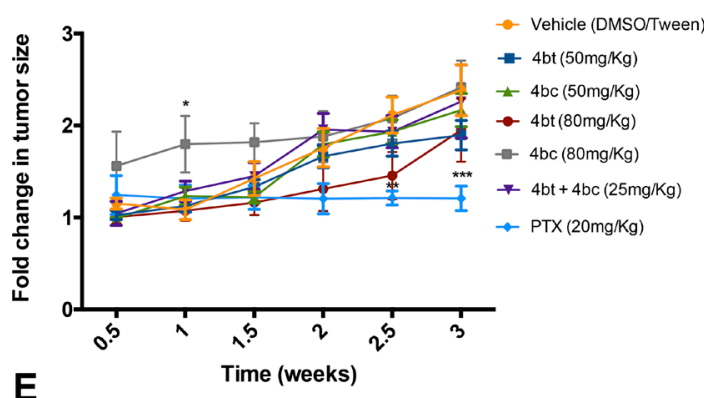

E

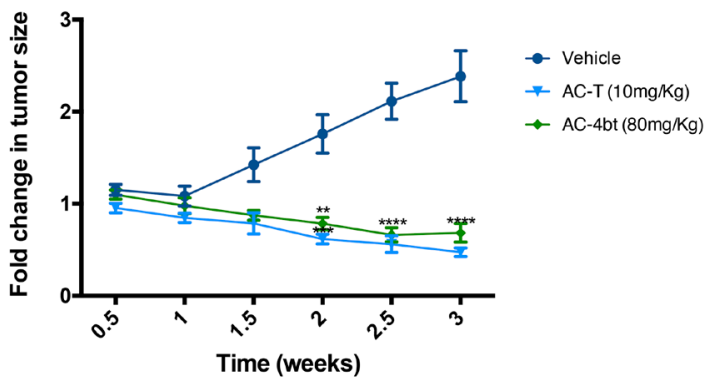

B

$\rightarrow$ Vehicle (DMSO/Tween)

$=4 \mathrm{bt}(50 \mathrm{mg} / \mathrm{Kg})$

$\pm 4 \mathrm{bc}(50 \mathrm{mg} / \mathrm{Kg})$

$-4 \mathrm{bt}(80 \mathrm{mg} / \mathrm{Kg})$

$-4 \mathrm{bc}(80 \mathrm{mg} / \mathrm{Kg})$

$\rightarrow 4 \mathrm{bt}(25 \mathrm{mg} / \mathrm{Kg})+4 \mathrm{bc}(25 \mathrm{mg} / \mathrm{Kg})$

$\rightarrow \operatorname{PTX}(20 \mathrm{mg} / \mathrm{Kg})$

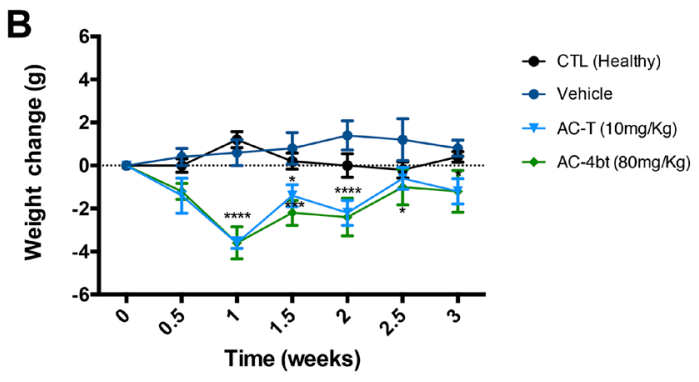

D

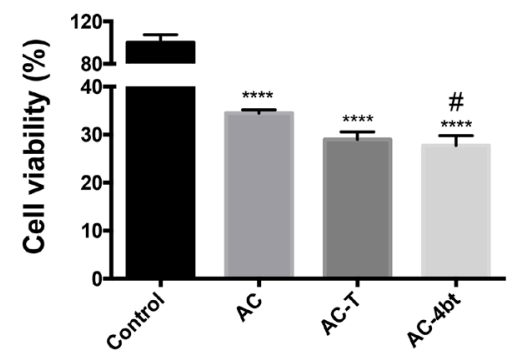

$\mathbf{F}$

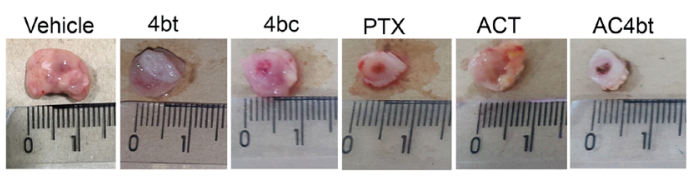

Figure 1: Body weight and tumor volume monitoring during monotherapy and drug combination therapy. (A) Body weight of animals submitted to monotherapy, administered with drug diluent (vehicle group), $4 \mathrm{bt}$ (50 or $80 \mathrm{mg} / \mathrm{Kg}$ ), $4 \mathrm{bc}(50 \mathrm{or} 80 \mathrm{mg} /$ $\mathrm{Kg}), 4 \mathrm{bt}+4 \mathrm{bc}(25 \mathrm{mg} / \mathrm{Kg}$ each) or paclitaxel $(20 \mathrm{mg} / \mathrm{Kg})$ or $(\mathbf{B})$ to drug combination, doxorubicin $(10 \mathrm{mg} / \mathrm{Kg})+$ cyclophosphamide (100 $\mathrm{mg} / \mathrm{Kg})$ in a single dose, followed by three doses of KIF11 inhibitor $4 \mathrm{bt}(80 \mathrm{mg} / \mathrm{Kg})$ or paclitaxel $(10 \mathrm{mg} / \mathrm{Kg})$ was monitored twice a week. Tumor volume for monotherapy (C) and drug combination (D) was also checked during all treatment time. (E) An in vitro survival assay with MDA-MB-231 cells was performed to evaluate if the association of paclitaxel or 4bt could potentiate antitumor effect of drug combination (doxorubicin and cyclophosphamide) treatment. (F) A representative image of tumor for each experimental group. Lines and columns represent mean \pm SEM of five animals used in each experimental group. ${ }^{*} p<0.05,{ }^{* * *} p<0.01,{ }^{* * *} p<0.001,{ }^{* * * *} p<0.0001$ as compared to control group; ${ }^{\#} p<0.05$ compared to AC treatment group. 
Table 2: Biochemical analysis of Balb-c nude mice bearing breast tumor

\begin{tabular}{|c|c|c|c|c|c|c|c|}
\hline & $\begin{array}{c}\text { Creatinine } \\
(\mathrm{mg} / \mathrm{dL})\end{array}$ & LDH (U/L) & $\operatorname{ALP}(\mathbf{U} / \mathbf{L})$ & GGT (U/L) & AST (UI/L) & ALT (UI/L) & Urea (mg/dL) \\
\hline CTL Healthy & $<0,2$ & $673.20 \pm 154.01$ & $109.40 \pm 8.24$ & 1 & $115.00 \pm 16.70$ & $30.00 \pm 2.45$ & $68.80 \pm 7.47$ \\
\hline Vehicle & $<0,2$ & $527.00 \pm 118.82^{* * *}$ & $79.00 \pm 12.44$ & $1.20 \pm 0.40$ & $98.40 \pm 26.31$ & $25.00 \pm 1.10$ & $56.60 \pm 4.88$ \\
\hline $4 \mathrm{bt}(50 \mathrm{mg} / \mathrm{Kg})$ & $<0,2$ & $677.60 \pm 84.90$ & $63.40 \pm 2.42$ & $1.00 \pm 0.63$ & $152.00 \pm 37.35$ & $28.60 \pm 3.67$ & $60.00 \pm 4.15$ \\
\hline $4 \mathrm{bc}(50 \mathrm{mg} / \mathrm{Kg})$ & $<0,2$ & $712.75 \pm 107.63$ & $67.75 \pm 8.47$ & $1.00 \pm 0.71$ & $132.50 \pm 26.69$ & $27.50 \pm 5.89$ & $53.50 \pm 4.92$ \\
\hline $4 \mathrm{bt}(80 \mathrm{mg} / \mathrm{Kg})$ & $<0,2$ & $552.20 \pm 133.08^{*}$ & $75.80 \pm 10.93$ & $<1$ & $150.00 \pm 40.31$ & $34.20 \pm 2.64$ & $68.40 \pm 4.76$ \\
\hline $4 \mathrm{bc}(80 \mathrm{mg} / \mathrm{Kg})$ & $<0,2$ & $537.80 \pm 122.98^{* *}$ & $93.80 \pm 14.69$ & 1 & $118.80 \pm 29.38$ & $29.40 \pm 4.50$ & $63.60 \pm 3.14$ \\
\hline $4 \mathrm{bt}+4 \mathrm{bc}(25 \mathrm{mg} / \mathrm{kg})$ & $<0,2$ & $705.80 \pm 331.33$ & $73.80 \pm 10.89$ & $1.60 \pm 2.25$ & $218.00 \pm 139.16^{*}$ & $41.60 \pm 20.95$ & $53.00 \pm 4.38$ \\
\hline Paclitaxel (20 mg/kg) & $<0,2$ & $464.50 \pm 50.5^{* * * *}$ & $86.50 \pm 10.5$ & $<1$ & $98.50 \pm 21.50$ & $21.50 \pm 1.50$ & $59.00 \pm 2.00$ \\
\hline AC-T & $<0,2$ & $424.00 \pm 70.21^{* * * * *}$ & $77.00 \pm 6.60$ & $<1$ & $108.75 \pm 19.18$ & $21.50 \pm 1.80$ & $54.25 \pm 1.92$ \\
\hline AC- $4 \mathrm{bt}$ & $<0,2$ & $398.20 \pm 98.17^{* * * * *}$ & $93.40 \pm 9.99$ & $<1$ & $100.80 \pm 19.96$ & $28.20 \pm 4.12$ & $60.60 \pm 7.17$ \\
\hline
\end{tabular}

LDH: Lactate dehydrogenase; ALP: alkaline phosphatase; GGT: Gamma-glutamyl transferase; AST: aspartate aminotransferase; ALT: alanine transaminase. Data represent mean \pm SEM. ${ }^{*} p<0.05,{ }^{* *} p<0.01,{ }^{* * * *} p<0.001,{ }^{* * * * *} p<0.0001$ as compared to control group (CTL Healthy).

animals from the first treatment group did not show any characteristic signal of peripheral neuropathy or impaired mobility, commonly presented by microtubule targeting drugs, as can be seen in Supplementary Videos 1 and 3.

Treatment with KIF11 inhibitor decreases intratumoral necrotic area To assess antiproliferative and antitumor effects of the treatments proposed on this work, histopathologic analysis of tumor sections of all animal groups were performed after HE staining.

As can be seen on Figure 2A, vehicle group presented a large intratumoral necrotic area showing a pattern of fast growing of the tumor cells during the period of study. When monotherapy with $4 \mathrm{bt}, 4 \mathrm{bc}$ or paclitaxel was performed (Figure 2B-2D), we observed a reduction in the size of necrotic area, and for $4 \mathrm{bt}$ treatment $(80 \mathrm{mg} /$ $\mathrm{kg}$ ), this reduction was associated with a slight decrease in tumor volume, assessed by caliper, during treatment time (Figure 1C and 1F). Association of KIF11 inhibitor 4bt in drug combination treatment regimen besides to cause a decrease in tumor volume it also caused a considerable reduction in intratumoral necrotic area (Figure $2 \mathrm{~F}$ ), even better than AC-T drug combination (Figure 2E), showing important antiproliferative activity in this tumor model.

To assess the tumor burden in one of the most common sites of metastasis for breast cancer, paraffinembedded sections of lungs were analyzed in a
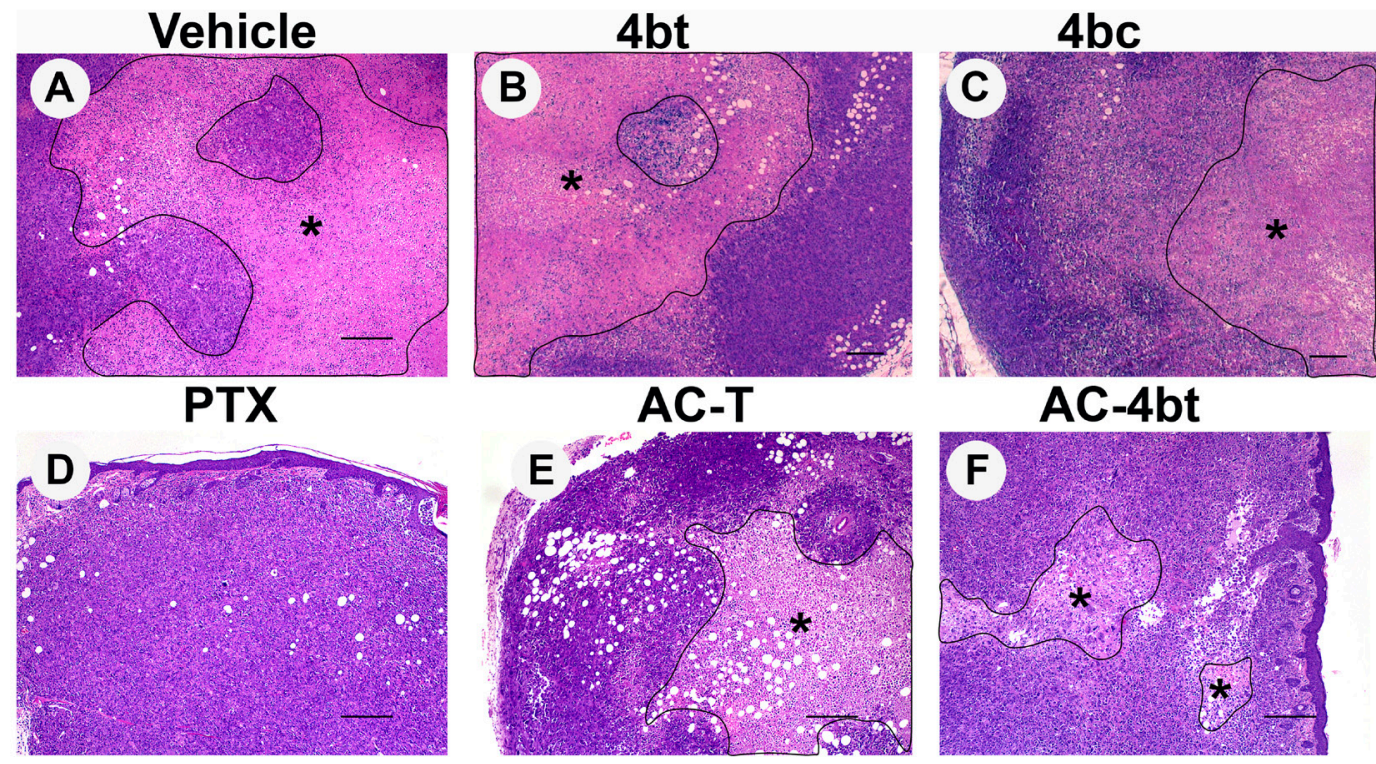

Figure 2: Histopathological analysis of tumor sections upon monotherapy or drug combination treatments. Representative images of paraffin-embedded sections of tumors stained with H\&E from the different experimental groups administered intraperitoneally (i.p.) with: (A) Vehicle, (B) 4bt (80 mg/Kg), (C) 4bc $(80 \mathrm{mg} / \mathrm{Kg}),(\mathbf{D})$ paclitaxel $(20 \mathrm{mg} / \mathrm{Kg}),(\mathbf{E})$ Doxorubicin (10 mg/Kg) + Cyclophosphamide (100 mg/Kg) followed by paclitaxel $(10 \mathrm{mg} / \mathrm{Kg})(\mathrm{AC}-\mathrm{T})$ and (F) Doxorubicin (10 mg/Kg) + Cyclophosphamide (100 $\mathrm{mg} / \mathrm{Kg}$ ) followed by KIF11 inhibitor 4bt (AC-4bt). Treatment with 4bt used as monotherapy or in drug combination prevent exacerbated tumor growth leading to a decrease in the extension of the central necrotic area (outlined and marked with asterisk). Bars: $250 \mu \mathrm{m}$ (A, D, $\mathrm{E}$ and $\mathrm{F})$ and $200 \mu \mathrm{m}(\mathrm{B}$ and $\mathrm{C})$. 
blinded manner, however none metastasis or any other histopathological changes were observed in nude-mice bearing breast tumor of all experimental groups compared to the control healthy group as shown in Supplementary Figure 1. This indicates that the established time for tumor growth before the beginning of treatment could be not enough for tumor metastasis and also that none of the treatment caused any toxicity for lungs.

\section{4bt decreases intratumoral KIF11 expression and leads to monoastral spindle formation in vivo}

KIF11 has been shown to be overexpressed in a broad range of cancer what contributes to tumorigenesis, being associated with a worse prognostic [18]. These findings lead us to question if KIF11 inhibitors could somehow regulate its expression besides to impair its activity. To test this hypothesis, we performed a western blot analysis of MDA-MB-231 cells control and treated with KIF11 inhibitors $4 \mathrm{bt}$ and $4 \mathrm{bc}$ at two different concentrations. Interestingly, it was observed that $4 \mathrm{bt}$ and $4 \mathrm{bc}$ regulated the expression levels of this protein, and this regulation was dose-dependent (Supplementary Figure 2). Thus, we aimed to evaluate the intratumoral expression of KIF11 in the in vivo model used in this study.

To examine the effects of the inhibitors on intratumoral KIF11 expression, tumor sections of treated and vehicle animals were immunostained for KIF11 analysis. As can be seen in Figure $3 \mathrm{~A}$ and 3B, tumors of vehicle animals showed superexpression of KIF11. This expression can be observed both in nucleus, even in cells that are not dividing, and in cytoplasm. It is also possible to visualize a great number of dividing cells presenting bipolar and multipolar spindle, as expected for MDAMB-231 cells [9, 28].

Monotherapy with KIF11 inhibitors led to a less intense expression of intratumoral KIF11, mainly with administration of 4bt, in which we can see KIF11 expression occurring predominantly in cytoplasm and a smaller number of cells dividing. Paclitaxel alone didn't cause any change on KIF11 levels. Drug combination of both $\mathrm{AC}-\mathrm{T}$ and $\mathrm{AC}-4 \mathrm{bt}$ showed a relevant role in downregulating KIF11 expression levels, and it is also possible to note that association of $4 \mathrm{bt}$ induced monoastral spindle formation as it was already described for in vitro treatment [26] (Figure 3A and 3B).

\section{Treatment with KIF11 inhibitor induces apoptotic cell death and decreases ALDH1-A1 expression}

To evaluate the mechanism behind tumor growth inhibition observed by tumor measure analysis caused by DHPMs, we assessed proliferation index and apoptotic cell death by Ki67 staining of tumor sections and TUNEL assay, respectively.
Monotherapy with KIF11 inhibitors 4bt and 4bc were responsible for a slight increase in $\mathrm{Ki} 67$ expression by breast tumor cells compared to vehicle group, as can be seen on Figure 4A and 4B. Drug combination using $\mathrm{AC}$ associated to $4 \mathrm{bt}$ as adjuvant therapy didn't cause significant changes in proliferation rate being similar to the results obtained by AC-T, as shown in Figure 4A and $4 \mathrm{~B}$. However, based on tumor volume monitored during treatment time we could assume that mainly drug combination was effective in decrease tumor growth. These data were corroborated by TUNEL analysis, where we can see that positive control paclitaxel and both drug combinations, AC-T and AC-4bt, substantially increase positive area staining showing a considerable apoptotic activity caused by these treatments (Figure 5A and 5B).

In a previous work of our research group, we evaluated the role of several KIF11 inhibitors on cancer stem cell (CSC) population in MDA-MB-231 cells throughout the analysis of CD44 and CD24 expression. We found that specifically these two inhibitors selected for this work, $4 \mathrm{bt}$ and $4 \mathrm{bc}$, were able to considerably reduce $\mathrm{CD}_{4}{ }^{+} /$ CD24- population. ALDH1-A1, an isozyme associated to cancer stem-cells in many solid tumors, is another breast CSC marker, involved in self-renewal, differentiation and self-protection. High ALDH1 expression is associated with early relapses; metastasis development and therapy resistance being correlated with poor clinical outcomes in breast cancer patients [29-35]. Moreover, it was shown a positive correlation between KIF11 and ALDH1 expression in MCF-7 and SKBR-3 cells [36]. So, we aimed to verify if KIF11 inhibitors could also reduce ALDH1-A1 contributing to a better response to treatment.

In ALDH1-A1 analysis we could note that 4bt was able to down regulate its expression in an expressive and significant way both when used as monotherapy and when used as adjuvant therapy with drug combination (Figure 6A) leading the median of the percentage of high positive and positive area from 34.31, in vehicle group, to 10.16 (4bt) and 4.26 (AC-4bt), and wide part of tumor was scored as low-positive. Treatment with paclitaxel and $4 \mathrm{bc}$ didn't cause significant changes in ALDH1-A1 expression being similar to vehicle group with a positive score (Figure 6B).

\section{DISCUSSION}

TNBC patients normally receive as standard care neoadjuvant chemotherapy with a combination of mitotic inhibitor, as taxanes, and a DNA intercalator, as anthracyclines. Despite the effectiveness of this therapeutic regimen, about 30 to $50 \%$ of patients still relapse with emergence of drug resistant clones, leading to poor overall survival $[1,6]$.

Taxanes function by binding to tubulin, an essential protein for cell division, motility, cell shape and intracellular transport. The disruption of microtubule 
dynamics caused by these drugs are responsible for activating the spindle checkpoint leading to cell death. However, since microtubules have other important roles in cell biology, these agents can also cause peripheral neuropathy as an adverse event by interfering with microtubule-based axonal transport $[37,38]$.

In this context KIFs have emerged as a prominent e promising strategy to fight tumor cells. Several recent studies have reported that KIF11 is highly expressed in several types of tumors and is often associated with chemotherapeutic drug resistance and poor prognosis [19, 21, 22, 39]. KIF11, or Kinesin Eg5, is the most well-studied protein of this family in clinical setting. Its overexpression generates genome instability and carcinogenesis in mouse models and it is also responsible for tumor angiogenesis [23, 40].

Despite the great results on preclinical studies, some disappointing results in clinical trials with KIF11 inhibitors were observed over the past years. There are some main reasons for this, like the fact that the doubling

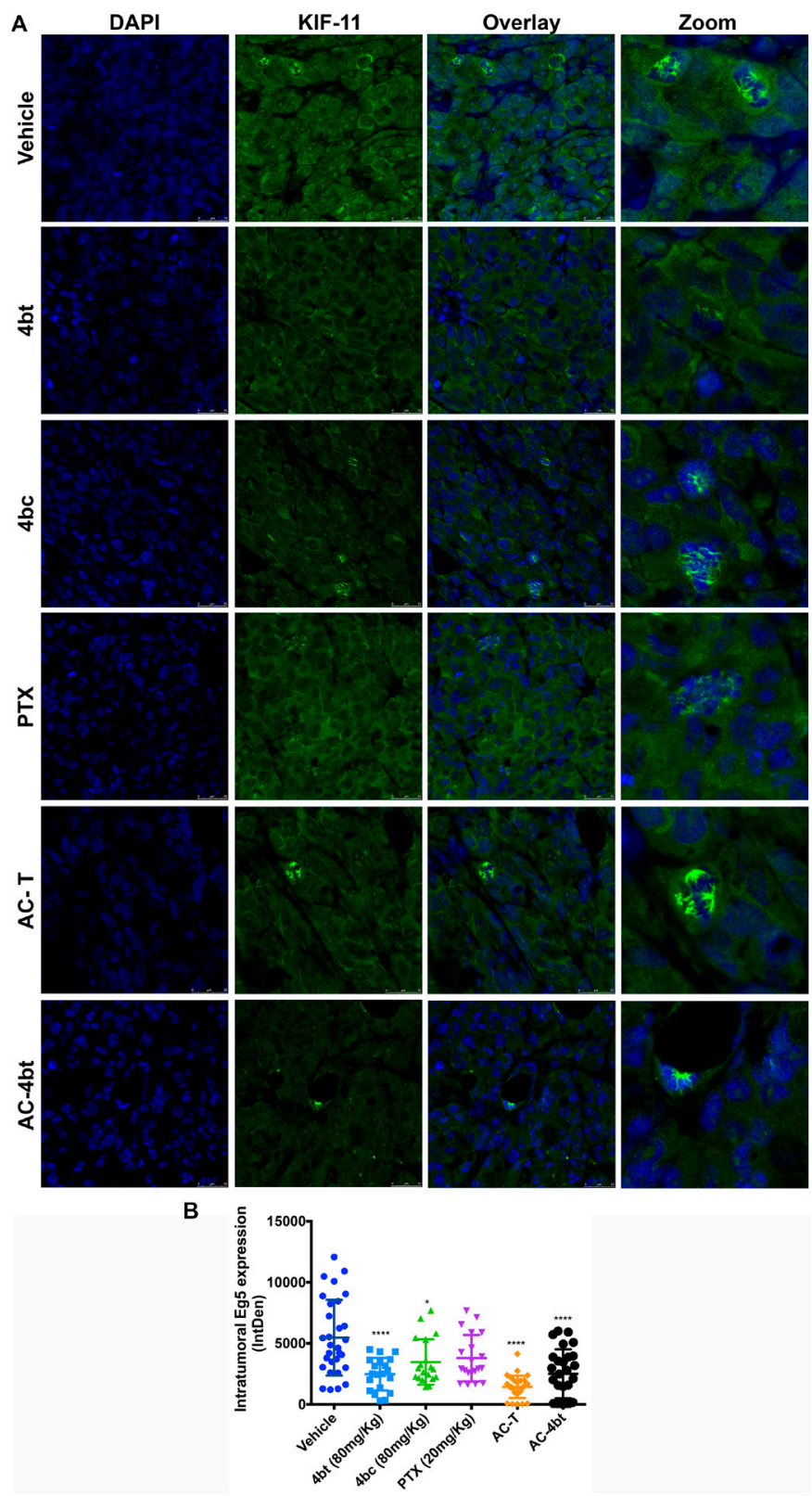

Figure 3: Analysis of intratumoral KIF11 expression. (A) Tumor sections from the different experimental groups administered intraperitoneally (i.p.) with: Vehicle, $4 \mathrm{bt}(80 \mathrm{mg} / \mathrm{Kg}), 4 \mathrm{bc}(80 \mathrm{mg} / \mathrm{Kg})$, paclitaxel $(20 \mathrm{mg} / \mathrm{Kg})$, Doxorubicin $(10 \mathrm{mg} / \mathrm{Kg})+\mathrm{Cyclophosphamide}$ $(100 \mathrm{mg} / \mathrm{Kg})$ followed by paclitaxel $(10 \mathrm{mg} / \mathrm{Kg})(\mathrm{AC}-\mathrm{T})$ and Doxorubicin $(10 \mathrm{mg} / \mathrm{Kg})+$ Cyclophosphamide $(100 \mathrm{mg} / \mathrm{Kg})$ followed by KIF11 inhibitor 4bt (AC-4bt) were immunostained for KIF11 (green) and genetic material (blue). (B) Integrated Density calculated by using sets containing 10 random images of each experimental group. 4bt or drug combinations were able to significantly decrease intratumoral KIF11 expression levels. Data represent mean \pm SEM of three independent experiments. ${ }^{*} p<0.05,{ }^{* * * *} p<0.0001$ as compared to control group (vehicle). Bars: $25 \mu \mathrm{m}$. 
time of human tumors is much longer than xenografts, suggesting a small proportion of mitotic cells in human tumors compared to animal xenografts [17]. Another reason is the development of drug resistance due to the emergence of point mutations in enzymatic domain of Eg5 that constitutes part of the drug-binding site [41]. Besides,
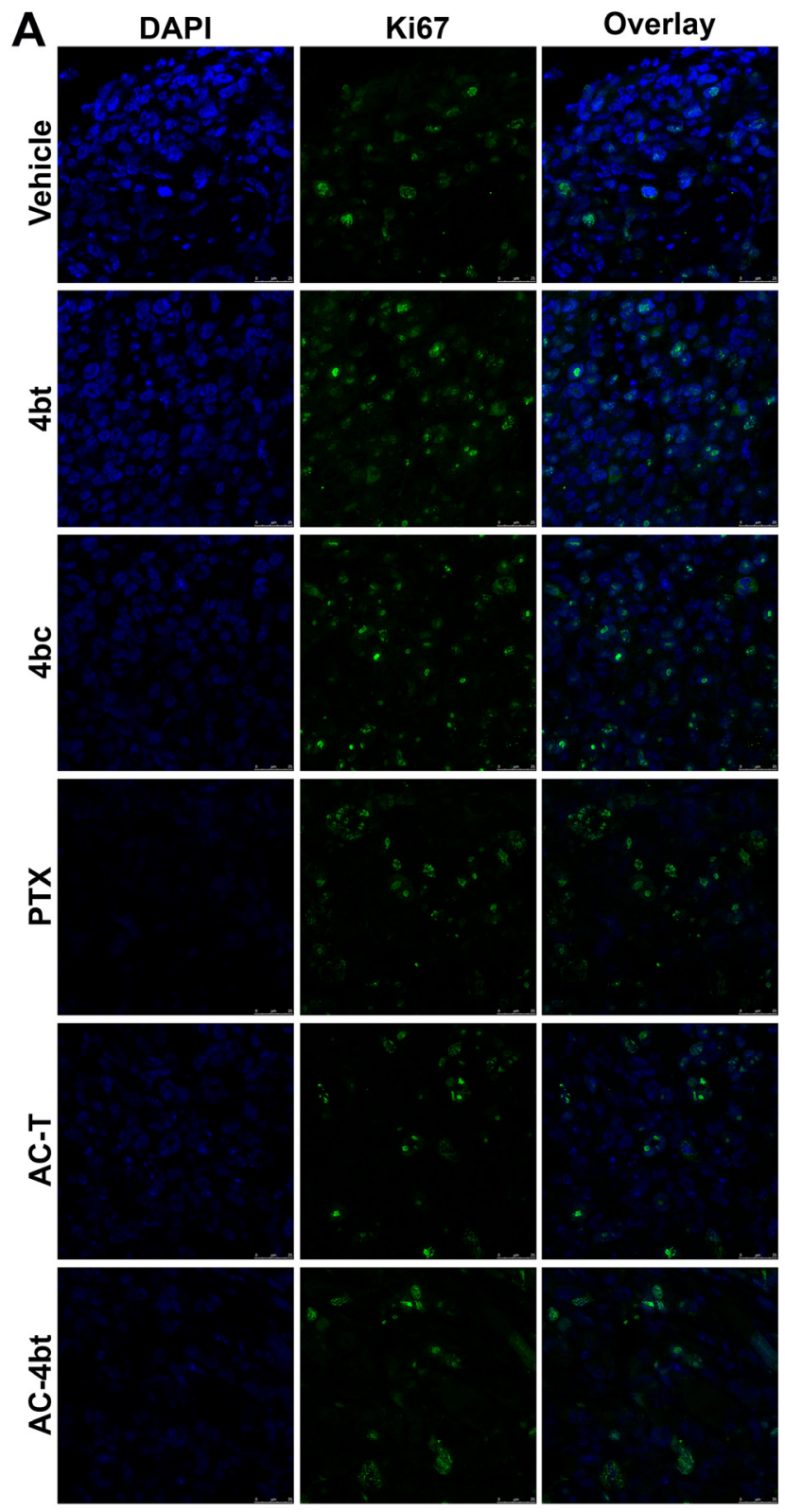

B

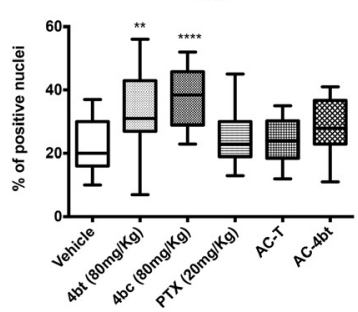

Figure 4: Proliferation analysis of tumor sections. (A) Tumor sections from the different experimental groups administered intraperitoneally (i.p.) with: Vehicle, $4 \mathrm{bt}(80 \mathrm{mg} / \mathrm{Kg}), 4 \mathrm{bc}(80 \mathrm{mg} / \mathrm{Kg})$, paclitaxel $(20 \mathrm{mg} / \mathrm{Kg})$, Doxorubicin $(10 \mathrm{mg} / \mathrm{Kg})+\mathrm{Cyclophosphamide}$ $(100 \mathrm{mg} / \mathrm{Kg})$ followed by paclitaxel $(10 \mathrm{mg} / \mathrm{Kg})(\mathrm{AC}-\mathrm{T})$ and Doxorubicin $(10 \mathrm{mg} / \mathrm{Kg})+$ Cyclophosphamide $(100 \mathrm{mg} / \mathrm{Kg})$ followed by KIF11 inhibitor 4bt (AC-4bt) were immunostained for Ki67 (green) and genetic material (blue). (B) Percentage of Ki67 positive nuclei for each experimental group. Data represent mean \pm SEM of three independent experiments. ${ }^{* *} p<0.01,{ }^{* * * *} p<0.0001$ as compared to control group (vehicle). Bars: $25 \mu \mathrm{m}$. 
as already mentioned, we have the neutropenia as the main dose-limiting toxicity [24, 42]. Even with the unsuccessful results in some clinical tests, the results in preclinical tests added to the absence of neurotoxic effects, indicate that this class of inhibitors can still be a good therapeutic option, especially if used in combination with other drugs.

In this work we propose the substitution of the taxane (paclitaxel) in the AC-T therapeutic breast cancer regimen with a KIF11 inhibitor, in the hope of preserving antitumoral activity while reducing toxicity.

Our data showed that 4bt, one of the KIF11 inhibitors evaluated on this work, was able to hold tumor growth when used as monotherapy, however it presented more pronounced antitumor effects when used in combination with other drugs, as already pointed for other KIF11 inhibitors [43, 44]. The great advantage in using this class of inhibitor is to minimize the intense and unpleasant adverse events causes by some class of drugs like taxanes. Neutropenia is the most common adverse effect presented by KIF11 inhibitors already analyzed on clinical trials $[45,46]$. Ispinesib was the first and is the most well characterized KIF11 inhibitor to enter in clinical trials [47]. In phase I trial in breast cancer, Ispinesib showed relevant antitumor activity and stabilization of the disease [48]. Among the reported side effects were neutropenia, increase in hepatic transaminases and diarrhea [46]. Besides, ispinesib was well-tolerated and had no indication of neurotoxicity $[49,50]$.
A

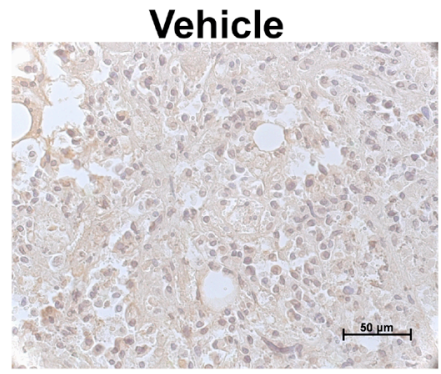

PTX

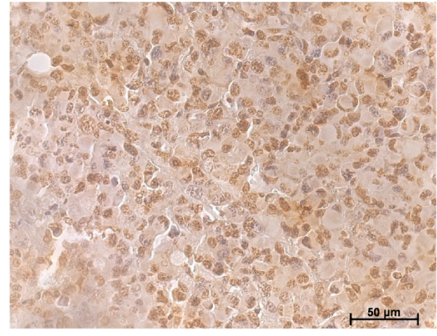

$4 b t$

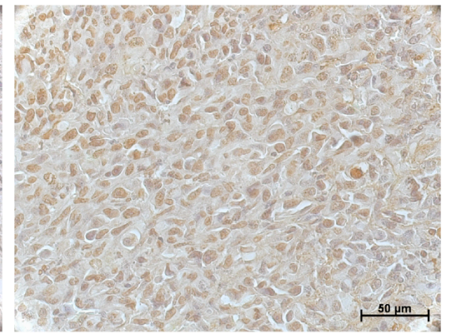

AC-T

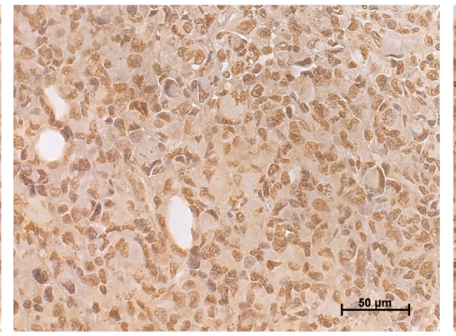

$4 \mathrm{bc}$

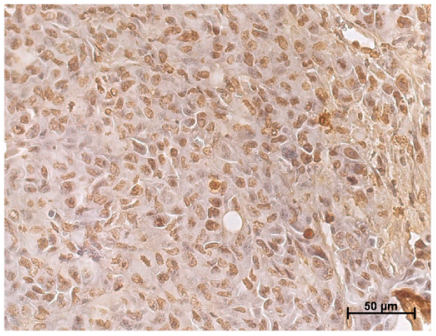

AC-4bt

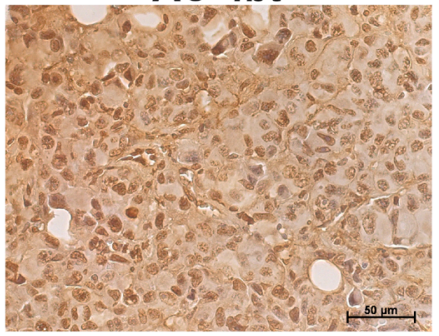

B

TUNEL

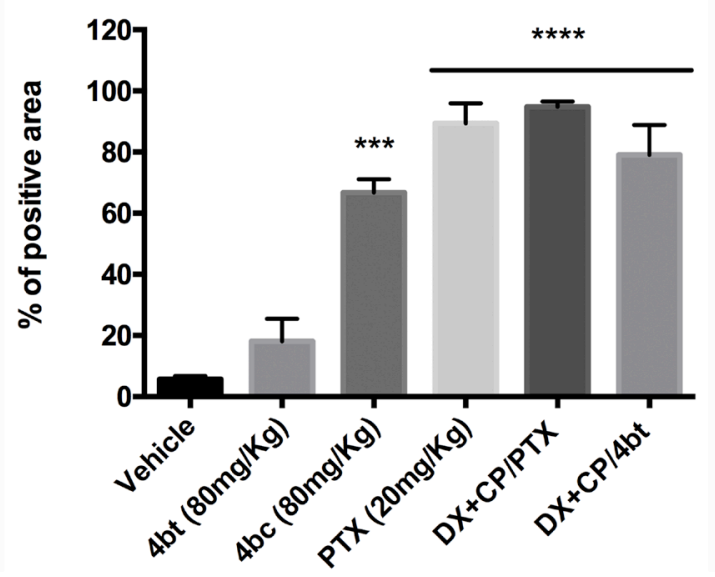

Figure 5: TUNEL analysis for apoptosis detection in tumor sections of xenografted Balb-c/nude mice. (A) Representative images of TUNEL assay of tumor sections from the different experimental groups administered intraperitoneally (i.p.) with: Vehicle, 4bt (80 mg/Kg), 4bc (80 mg/Kg), paclitaxel (20 mg/Kg), Doxorubicin $(10 \mathrm{mg} / \mathrm{Kg})+$ Cyclophosphamide $(100 \mathrm{mg} / \mathrm{Kg})$ followed by paclitaxel $(10 \mathrm{mg} / \mathrm{Kg})(\mathrm{AC}-\mathrm{T})$ and Doxorubicin $(10 \mathrm{mg} / \mathrm{Kg})+$ Cyclophosphamide $(100 \mathrm{mg} / \mathrm{Kg})$ followed by KIF11 inhibitor $4 \mathrm{bt}(\mathrm{AC}-4 \mathrm{bt})$. (B) Quantitative analyses of apoptotic cell area for each experimental group. Data represent mean $\pm \mathrm{SEM}$ of three independent experiments. ${ }^{* * *} p<0.001,{ }^{* * * *} p<0.0001$ as compared to control group (vehicle). Bars: $50 \mu \mathrm{m}$. 
In our study, we verified some level of neutropenia in animals treated with $4 \mathrm{bt}(80 \mathrm{mg} / \mathrm{Kg})$, however this alteration was not statistically significant, as it is common in clinical trials with this class of inhibitors [24], what makes it an attractive therapeutic option. Also, we could verify some evident neurotoxicity effects induced by paclitaxel a few minutes after administration as observed on supplemental videos. To achieve a considerable breast tumor growth inhibition on our model, a concentration of $20 \mathrm{mg} / \mathrm{Kg}$ of paclitaxel was intraperitoneally administered. Animals that received this treatment lost their motor control and could not move their hind legs normally. None similar effect was verified in DHPMs treatment groups, even at the highest concentrations tested $(80 \mathrm{mg} / \mathrm{Kg})$. The low expression of KIF11 in non-tumoral tissues that are not proliferating results in a lower toxicity of KIF11-targeted therapy when compared to traditional anti-mitotic therapies [51].
Several works have shown a correlation between high expression levels of Eg5 and poor prognosis in breast cancer [18], hepatocellular carcinoma [19], thymic malignancies [52], laryngeral squamous cell carcinoma [20], renal cell carcinoma [22] and in non-muscle invasive bladder urothelial carcionoma [39]. So, we aimed to evaluate if DHPMs could affect the expression levels of intratumoral KIF11 besides to interfere in its activity as elucidated in a previous work of our research group [26]. $4 \mathrm{bt}$ both alone and in combination with other drugs, was able to decrease intratumoral KIF11 expression in vivo upon intraperitoneally administration. These data differ from the results obtained in vitro, since in the latter, $4 \mathrm{bt}$ inhibitor caused a slight increase in the expression of $\mathrm{KIF} 11$ when the $\mathrm{IC}_{50}$ concentration was used, and in the $i n$ vivo assay, both $4 \mathrm{bc}$ and $4 \mathrm{bt}$ decreased the expression of this protein. This difference may be due to both the drug
A
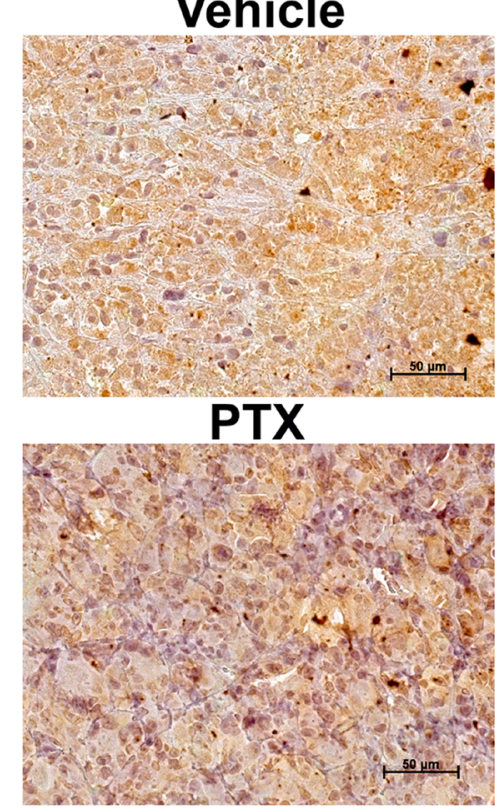

4bt

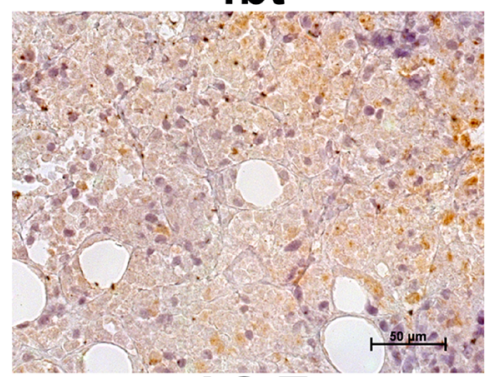

AC-T

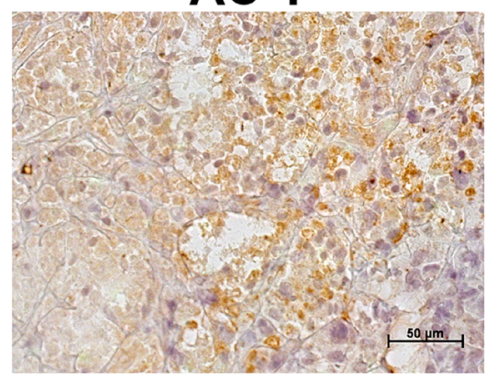

$4 b c$

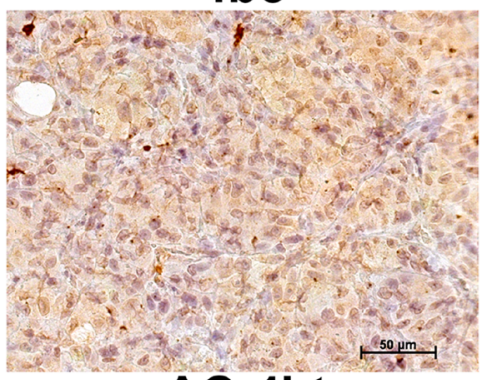

AC-4bt

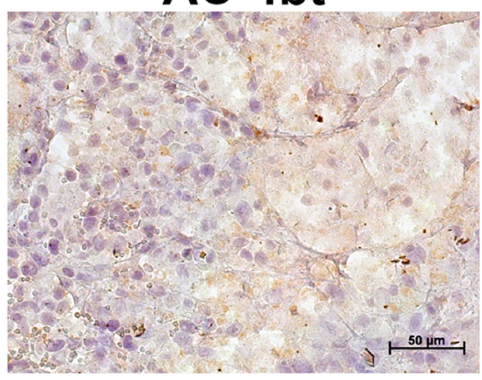

B

\begin{tabular}{lccc}
\hline $\begin{array}{c}\text { Experimental } \\
\text { Group }\end{array}$ & $\begin{array}{c}\text { \% of high positive and positive area } \\
\text { Median }\end{array}$ & Mean \pm SD & Score \\
\hline Vehicle & 34.31 & $30.14 \pm 8.70$ & POS \\
4bt & 10.16 & $10.81 \pm 4.03^{\cdots \cdots}$ & L-POS \\
$4 \mathrm{bc}$ & 18.04 & $19.32 \pm 7.02$ & POS/L-POS \\
PTX & 33.81 & $31.33 \pm 13.08$ & POS \\
AC-T & 11.45 & $10.07 \pm 7.88^{\cdots \cdots}$ & L-POS \\
AC-4bt & 4.26 & $12.31 \pm 12.95^{\cdots+}$ & L-POS \\
\hline
\end{tabular}

Figure 6: ALDH1-A1 expression analysis in tumor sections of xenografted Balb-c/nude mice. (A) Representative images of ALDH1-A1 immunostaining of tumor sections from the different experimental groups administered intraperitoneally (i.p.) with: Vehicle, 4bt (80 mg/Kg), 4bc (80 mg/Kg), paclitaxel $(20 \mathrm{mg} / \mathrm{Kg})$, Doxorubicin $(10 \mathrm{mg} / \mathrm{Kg})+$ Cyclophosphamide $(100 \mathrm{mg} / \mathrm{Kg})$ followed by paclitaxel $(10 \mathrm{mg} / \mathrm{Kg})(\mathrm{AC}-\mathrm{T})$ and Doxorubicin $(10 \mathrm{mg} / \mathrm{Kg})+$ Cyclophosphamide $(100 \mathrm{mg} / \mathrm{Kg})$ followed by KIF11 inhibitor 4bt (AC-4bt). (B) Quantitative analyses highly positive and positive area with indication of the score for each experimental group. L-POS: low positive; POS: positive. Data represent mean \pm SEM of three independent experiments. ${ }^{* * *} p<0.001,{ }^{* * * *} p<0.0001$ as compared to control group (vehicle). Bars: $50 \mu \mathrm{m}$. 
concentration that reaches the tumor and the influence of the tumor microenvironment in the in vivo model.

The effect of this inhibitor was kept even with the influence of tumor microenvironment as we can observe the formation of monoastral spindle in dividing cells.

As KIF11 is involved with breast cancer development, drug resistance [53] and poor prognosis, the control of its expression can improve results obtained with chemotherapy, being responsible for better outcomes. In addition to this, $4 \mathrm{bt}$ also exerts growth inhibitory effect in vivo, being responsible for induction of apoptosis cell death in tumor and leading to a slower growth of tumor cells that presented smaller areas of necrosis in the core of the tumor.

With regards to Ki-67 expression, DHPMs cause a cell cycle arrest at $\mathrm{G} 2 / \mathrm{M}$ as previously reported by our group [26]. Treatment of MDA-MB-231 cells in vitro with $4 \mathrm{bt}$ and $4 \mathrm{bc}$ inhibitors didn't lead to a cell cycle arrest at G2/M because of the marked cytotoxic effect and rapid elimination of cells. However, our in vivo experiments pointed for a slower induction of apoptosis, confirmed by the great amount of intratumoral cells presenting monoastral spindle, so we have the occurrence of cells arrested in $\mathrm{G} 2 / \mathrm{M}$ phase. It is known that $\mathrm{Ki}-67$ levels are higher in $\mathrm{G} 2$ phase and mitosis $[54,55]$, so this result in the increase in Ki-67 levels in tumors of xenografted mice treated with $4 \mathrm{bt}$ and $4 \mathrm{bc}$ alone, could be reflecting this phase of arrest, and not an absence of antiproliferative effect, since tumors showed some volume reduction, mainly with 4 bt treatment.

Despite having the best antitumor activity in vitro, $4 \mathrm{bc}$ inhibitor was not able to reduce the tumor volume in xenografted animals. This may have occurred due to the concentration used in the in vivo tests, which had its maximum dose limited by drug solubility. As shown in previously published work of our research group, this inhibitor presented a considerably higher $\mathrm{IC}_{50}$, which indicates that higher doses may be also necessary for it to maintain its activity in vivo. These data also justify the fact that $4 \mathrm{bc}$ treatment has shown interesting results regarding Ki67 expression and TUNEL analysis,

Another interesting finding was the downregulation of ALDH1-A1 expression upon treatment with $4 \mathrm{bt}$ both as monotherapy and in combination with AC. This corroborates with our in vitro data in which 4bt considerably decrease cancer stem cells (CSC) represented by $\mathrm{CD}_{4} 4^{+} / \mathrm{CD} 24^{-}$population [26]. ALDH1-A1 is an important marker of CSCs and its high expression is correlated with poorer overall survival in breast cancer patients $[31,56]$. Pei and collaborators (2019) showed that self-renewal of breast cancer cells is enhanced by endogenous KIF11 through activating Wnt/ $\beta$-catenin signaling pathway contributing to the breast cancer stem cell features. They have shown that reduced levels of CSC markers as Oct4, Nanog, ALDH1 and CD44 were observed in breast cancer cells with silenced KIF11 [36]. Moreover, KIF11 expression was positively correlated to ALDH1 in oesophageal squamous cell carcinoma [57].

It was also reported that ALDH1-A1 and ALDH2-A1 have a role in the conversion of activated cyclophosphamide (4-hydroperoxycyclophosphamide) to the inactive excretory carboxyphosphamide providing to $\mathrm{CSC}$ drug protection and radiation resistance $[58,59]$. This interesting result was not observed in animals treated with paclitaxel.

In conclusion, our study provides extensive evidence to demonstrate that KIF11 inhibitor $4 \mathrm{bt}$ showed pronounced antitumor activity, acting in key points of tumorigenesis and cancer progression in in vivo xenograft model of triple negative breast cancer. These considerations imply that KIF11 inhibitors may represent a promising strategy to be used as adjuvant therapy in breast cancer treatment regimen and may improve TNBC patients' outcomes showing considerably fewer side effects. Furthermore, this inhibitor has shown other interesting roles for tumor inhibition, like down-regulation of KIF11 and ALDH1-A1, particularly when combined with existing treatments.

\section{MATERIALS AND METHODS}

\section{Animals}

Animal work was performed using 8-week-old female Balb-c/nude mice. Animals were kept in the Bioassay Laboratory at Catholic University of Brasília housed in five animals per cage under $12 \mathrm{~h}$ light-dark cycles at a controlled temperature $\left(23^{\circ} \mathrm{C} \pm 2{ }^{\circ} \mathrm{C}\right)$, with water and food ad libitum. After tumor inoculation, mice were randomized into treatment groups ( $n=5$ per group). This study was approved by the Committee on Animal Research and Ethics of the Catholic University of Brasília (CEUA/UCB - Protocol 009/16).

\section{Tumor induction and treatment}

Mice were anesthetized with ketamine $(80 \mathrm{mg} / \mathrm{kg}$ of body weight) and xylazine (20 mg/ $\mathrm{kg}$ of body weight) solution. $2 \times 10^{6}$ MDA-MB-231 cells in PBS/20\% type I Collagen $(100 \mu \mathrm{L})$ were inoculated in the fourth right mammary fat pad. After tumor establishment, about 5 weeks after inoculation, mice were randomized into experimental groups ( $n=5$ per group), and treatment started.

Experiments were performed in two phases, in the first one, DHPMs were used as monotherapy, and experimental groups comprised to: 1) Control (Healthy animals); 2) Vehicle (1\% Tween 80/6.25\% DMSO in PBS, $\mathrm{pH} 7.4) ; 3$ ) 4bt (50 mg/kg); 4) 4bc (50 mg/Kg); 5) 4bt (80 $\mathrm{mg} / \mathrm{kg})$; 6) 4bc (80 mg/Kg); 7) 4bt + 4bt (25 mg/Kg each); 8) paclitaxel $(20 \mathrm{mg} / \mathrm{Kg}$ - diluted in PBS from a solution 
of $6 \mathrm{mg} / \mathrm{mL}$ in purified polyoxyl castor oil and $49.7 \%(\mathrm{v} / \mathrm{v})$ of dehydrated alcohol and sodium metabisulfite). Doses and schedules were determined based on previous works with the same class of compounds $[38,60]$ and maximal dose of $80 \mathrm{mg} / \mathrm{Kg}$ was established taking in to account the solubility of the inhibitors used in this work.

In the second phase, the DHPM that showed effectiveness in in vivo treatment, 4bt, was used as adjuvant therapy in combination with standard treatment regimen for invasive breast cancer: 1) AT-C: Doxorubicin (Adriamycin) (DX - $10 \mathrm{mg} / \mathrm{Kg})+$ Cyclophosphamide $(\mathrm{CP}-100 \mathrm{mg} / \mathrm{Kg})$ in a single dose, followed by three doses of paclitaxel $(10 \mathrm{mg} / \mathrm{Kg}$ twice a week), used as positive control; or 2) AT-4bt: Doxorubicin (Adriamycin) (DX - $10 \mathrm{mg} / \mathrm{Kg})+$ Cyclophosphamide (CP - $100 \mathrm{mg}$ / $\mathrm{Kg})$ in a single dose, followed by three doses of $4 \mathrm{bt}(80$ $\mathrm{mg} / \mathrm{Kg}$ twice a week). All treatments were administered intraperitoneally (i.p) (Figure 7).

\section{Weight and tumor growth monitoring}

Tumor length (1) and width (w) were measured with a caliper and recorded every 3-4 days and tumor volume was calculated using the following formula $\mathrm{V}\left(\mathrm{mm}^{3}\right)=$ $\left(1 \times w^{2}\right) / 2$. Animal weight was also monitored with help of a digital scale twice a week.
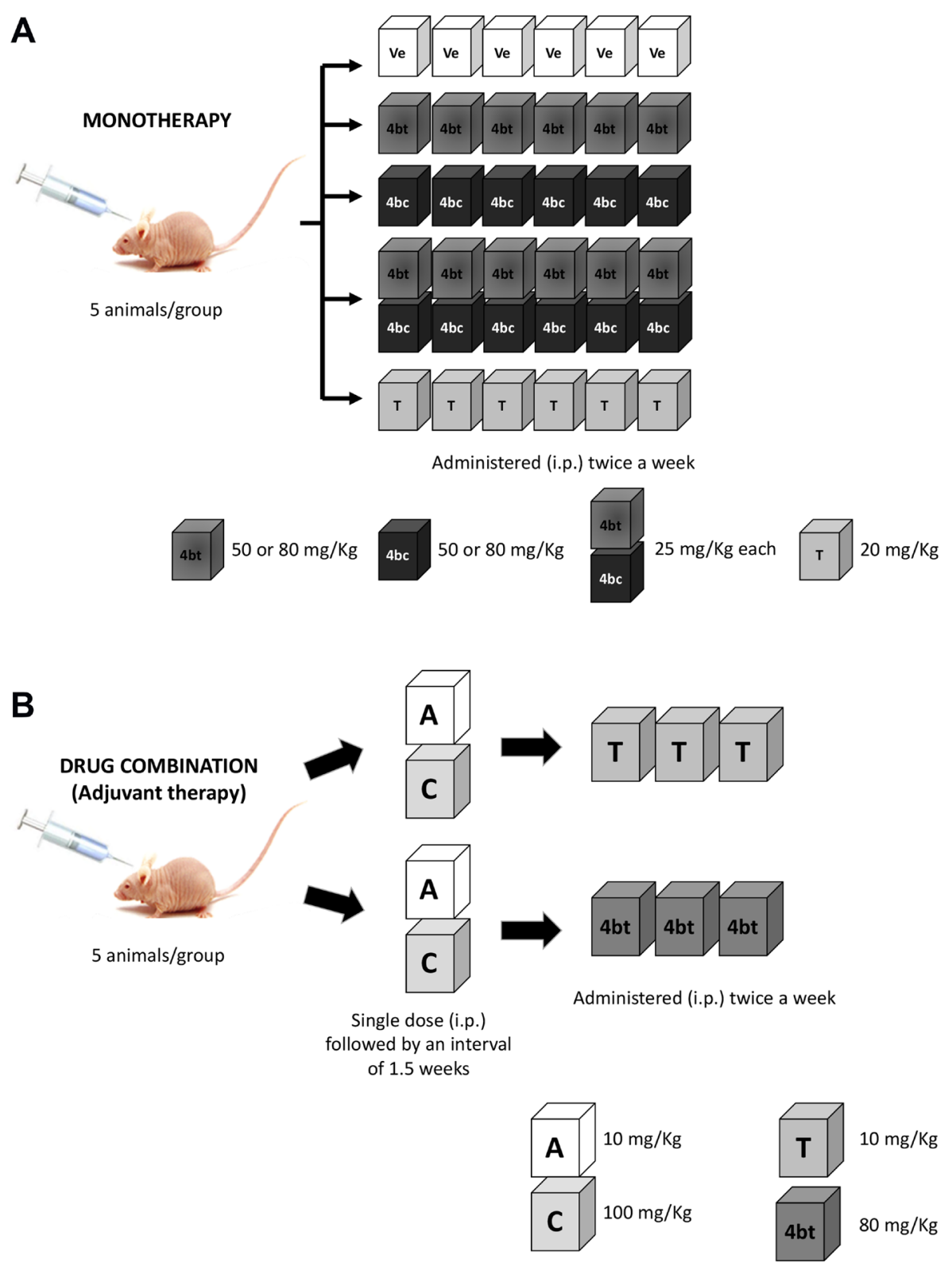

Figure 7: Scheme of therapeutic regimen applied in Balb-c/nude mice bearing breast cancer. (A) For monotherapy, animals were administered i.p. with six doses of $4 \mathrm{bt}$, $4 \mathrm{bc}(50 \mathrm{or} 80 \mathrm{mg} / \mathrm{Kg}), 4 \mathrm{bt}+4 \mathrm{bc}(25 \mathrm{mg} / \mathrm{Kg}$ each $)$ or paclitaxel $(20 \mathrm{mg} / \mathrm{Kg})$ twice a week. (B) For drug combination, animals received one dose of doxorubicin $(10 \mathrm{mg} / \mathrm{Kg})+$ cyclophosphamide $(100 \mathrm{mg} / \mathrm{Kg})$ i.p. and after $1.5 \mathrm{weeks}$ three doses of $4 \mathrm{bt}(80 \mathrm{mg} / \mathrm{Kg})$ or paclitaxel $(10 \mathrm{mg} / \mathrm{Kg})$ were administered twice a week. 


\section{Complete Blood Count (CBC) and biochemical exams}

Blood samples were collected in appropriate tubes for hematological (WBC, NEUT, LYPMPH, MONO, EOS, BASO, RBC, HGB, HCT, MCV, MCH, MCHC, RDW, PLT MPV) and biochemical (Creatinine, LDH, ALP, GGT, ALT, AST and urea) parameters analysis. All the tests were performed in collaboration by Sabin Diagnostic Laboratory.

\section{Histological analysis}

Tumors and lungs were fixed in $10 \%$ buffered formalin and processed for paraffin embedding. Processed material was sectioned at $5 \mu \mathrm{m}$, and sections were stained with hematoxylin \& eosin (HE) for analysis under the light microscope Axiovert (Zeiss, Germany). Tumor and lung sections were analyzed for general histopathological assessment.

\section{Analysis tumor cell apoptosis by TUNEL assay}

The level of apoptosis in tumor sections was determined by TUNEL assay. TUNEL staining was performed on paraffin-embedded sections using ClickiT $^{\mathrm{TM}}$ TUNEL Colorimetric IHC Detection Kit (Invitrogen, Carlsbad - USA) according to the manufacturer's protocol. Briefly, the sections were dewaxed, rehydrated, and immersed in $4 \%$ paraformaldehyde fixative solution for 15 minutes. They were then washed and incubated with proteinase $\mathrm{K}$ for $20 \mathrm{~min}$ at room temperature. The slides were washed with PBS for 5 minutes, and immersed in 4\% paraformaldehyde fixative solution again for 5 minutes at room temperature. Slides were then washed with PBS (twice, for 5 minutes) and rinsed with deionized water. Samples were incubated in TdT Reaction Buffer for 10 minutes at $37^{\circ} \mathrm{C}$. The TdT reaction buffer was gently removed using paper towels and slides were incubated with TdT Reaction Mixture for another hour at $37^{\circ} \mathrm{C}$ in a humidified chamber. After being rinsed with $\mathrm{PBS}$, slides were immersed in $2 \mathrm{X} \mathrm{SSC}$ for 15 minutes, in order to fully quench TdT reaction. Slides

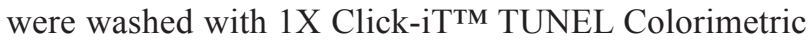
Wash solution and incubated with the Click-iT ${ }^{\mathrm{TM}}$ TUNEL Colorimetric Reaction cocktail for 30 minutes at $37^{\circ} \mathrm{C}$, protected from light. Slides were then rinsed respectively with PBS, 1X Click-iT TM TUNEL Colorimetric Wash solution and deionized water. Samples were then incubated with 1X Streptavidin-Peroxidase Conjugate at room temperature for 30 minutes in a humidified chamber and later washed 3 times with PBS before being rinsed with deionized water. Finally, slides were developed using the manufacturer's DAB Reaction Mixture (1:20 dilution of DAB Chromogen in DAB Substrate Buffer), washed with deionized water and counterstained with hematoxylin for analysis with light microscope Axiovert (Zeiss, Germany).

After acquisition, images were submitted to a semi-quantitative analysis using the IHC Profiler plugin (National Institute of Health) from ImageJ software. Images were submitted to a deconvolution process, and histogram profiles, corresponding to pixel intensity as well as a stain-positivity percentage value derived from a scoring system based on optical density, were automatically generated. Areas rated as highly positive or positive were considered for analysis.

\section{Analysis of intratumoral KIF 11, ALDH1-A1 and Ki67 expression}

In order to evaluate the role of KIF-11 inhibitors in some key features for tumor progression and development, we analyzed tumor sections for the levels of KIF-11, ALDH1-A1 and Ki67 expression by immunofluorescence (IF) or immunohistochemistry. Immunostaining was performed on $5 \mu \mathrm{m}$ sections of formalin-fixed paraffinembedded (FFPE) tissue. Tissue slides were baked, deparaffinized in xylene and passed through graded alcohols for rehydration. Antigen retrieval was achieved submitting samples to a $10 \mathrm{mM}$ Trisodium Citrate solution, $\mathrm{pH} 6.0$ in a steam pressure cooker at $100^{\circ} \mathrm{C}$ for 10 minutes. Slides were then left immersed in the Trisodium Citrate solution at room temperature for 20 minutes before being washed with PBS/0.025\% Triton. The area around each section was delimited by a hydrophobic liquid blocker (PAP-Pen) in order to assure homogeneous distribution of reagents and antibodies. Slides were pretreated with $1 \%$ skimmed milk/2,5\% BSA/8\%Fetal Bovine Serum+PBS for 30 minutes, washed and subsequently incubated with the respective primary antibodies (rabbit anti-KIF11 1:50; rabbit anti-ALDH1A1 - 1:100 - and rabbit anti Ki$67-1: 50$ - polyclonal antibodies) overnight at $4{ }^{\circ} \mathrm{C}$, inside a humidified chamber.

Slides were then washed in PBS/0.025\% Triton, incubated at room temperature in the dark with (1:500) Alexa Fluor 488-Anti-rabbit secondary antibody, for KIF-11 and Ki67, or (1:250) Goat anti-rabbit HRP, for ALDH1-A1 for 1 hour, washed three times with PBS. Slides destined for immunofluorescence were stained with DAPI (300 nM) and mounted with Fluoromount-G mounting medium (Electron Microscopy Sciences, Hatfield - USA) and specimens observed under a laser scanning confocal microscope TCS SP5 (Leica, Wetzlar, HE, Germany). Slides for ALDH1-A1 analysis were counterstained with hematoxylin and analyzed under light microscope Axiovert (Zeiss, Germany).

For ALDH1-A1 quantification of positive areas, IHC Profiler plug-in was used as previously described for TUNEL analysis. 


\section{Viability assay}

As we hypothesized that KIF11 inhibitors could potentiate antitumor effect when used in combination with conventional drugs for invasive breast cancer, we performed an in vitro viability assay using MDA-MB-231 cells to test this hypothesis. $5 \times 10^{3}$ MDA-MB-231 cells were plated in 96-well plates and treated with DHPM (4bt), the KIF11 with best results in the first phase of the in vivo tests, or paclitaxel in combination with doxorubicin and cyclophosphamide. Cells were treated first with doxorubicin + cyclophosphamide $(0.12 \mu \mathrm{M}$ and $2.5 \mu \mathrm{M}$, respectively) for $24 \mathrm{~h}$. After this period of incubation, fresh medium was added to the wells for $48 \mathrm{~h}$ followed by addition of $\mathrm{IC}_{50}$ of paclitaxel $(0.15 \mu \mathrm{M})$ or $4 \mathrm{bt}(17.91 \mu \mathrm{M})$ for $72 \mathrm{~h}$. Cytotoxicity was determined using PrestoBlue Cell Viability Reagent according to the manufacturer's instructions. Absorbance readings were measured by a spectrophotometer. Cell viability was normalized to control (vehicle only).

\section{Statistical analysis}

Data were expressed as mean \pm SEM. Statistical analyses and significance were determined by ANOVA with post-hoc comparison by Bonferroni test using GraphPad PRISM software version 6.0. A $P$ value of $<0.05$ was considered statistically significant.

\section{Abbreviations}

AC-T: Drug combination of Doxorubicin Hydrochloride (Adriamycin) (A), Cyclophosphamide (C) and Paclitaxel (Taxol) (T); ALDH1-A1: Aldehyde dehydrogenase 1; TNBC: Triple Negative Breast Cancer; KIF11: Kinesin Family Member 11; DHPM: dihydropyrimidin-2(1H)-ones or -thiones; MAP: Microtubule Associated Proteins; PTX: Paclitaxel; TUNEL: Terminal deoxynucleotidyl transferase dUTP nick end labeling; $\mathrm{CBC}$ : Complete Blood Count; LDH: Lactate dehydrogenase; ALP: alkaline phosphatase; GGT: Gamma-glutamyl transferase; ALT: alanine transaminase; AST: aspartate aminotransferase; MPV: mean platelet volume; MCV: mean corpuscular volume; MHC: Mean corpuscular hemoglobin; MCHC: mean corpuscular hemoglobin concentration; RDW: red cell distribution width; WBC: white blood cells.

\section{Author contributions}

BCG designed, performed experiments, collect analyzed data and wrote the manuscript. DCB, ALAB, MJXV, LF, performed experiments, collect and analyzed data and reviewed the manuscript. FN, performed experiments and reviewed the manuscript. LMR, synthesized the KIF11 inhibitors and reviewed the manuscript. MBC, performed histopathological analysis and reviewed the manuscript. BADN, was responsible for the synthesis of the DHPMs tested herein and reviewed the manuscript. JRC and SNB, designed the experiments and reviewed the manuscript.

\section{ACKNOWLEDGMENTS}

This work was supported by CAPES/PNDP fellowship. The authors also thank all the support from Graduate Program in Molecular Pathology, CNPq and FAPDF. We would like to specially thank to Sabin Laboratory Research Support Nucleus for performing all the hematological and biochemistry tests, and also to Bioassays Laboratory of Catholic University of Brasília that yielded the in vivo tests.

\section{CONFLICTS OF INTEREST}

Authors have no conflicts of interest to declare.

\section{REFERENCES}

1. Foulkes WD, Smith IE, Reis-Filho JS. Triple-negative breast cancer. N Engl J Med. 2010; 363:1938-48. https:// doi.org/10.1056/NEJMra1001389. [PubMed]

2. Kim C, Gao R, Sei E, Brandt R, Hartman J, Hatschek T, Crosetto N, Foukakis T, Navin NE. Chemoresistance Evolution in Triple-Negative Breast Cancer Delineated by Single-Cell Sequencing. Cell. 2018; 173:879-93.e13. https://doi.org/10.1016/j.cell.2018.03.041. [ [PubMed]

3. Waterhouse MP, Ugur R, Khaled WT. Therapeutic and Mechanistic Perspectives of Protein Complexes in Breast Cancer. Front Cell Dev Biol. 2019; 7:335. https://doi. org $/ 10.3389 /$ fcell.2019.00335. [PubMed]

4. Deepak KGK, Vempati R, Nagaraju GP, Dasari VR, S N, Rao DN, Malla RR. Tumor microenvironment: Challenges and opportunities in targeting metastasis of triple negative breast cancer. Pharmacol Res. 2020; 153:104683. https:// doi.org/10.1016/j.phrs.2020.104683. [PubMed]

5. Anders C, Carey LA. Understanding and treating triplenegative breast cancer. Oncology (Williston Park). 2008; 22:1233-39; discussion 1239-40, 1243. [PubMed]

6. Liedtke C, Mazouni C, Hess KR, André F, Tordai A, Mejia JA, Symmans WF, Gonzalez-Angulo AM, Hennessy B, Green M, Cristofanilli M, Hortobagyi GN, Pusztai L. Response to neoadjuvant therapy and long-term survival in patients with triple-negative breast cancer. J Clin Oncol. 2008; 26:1275-81. https://doi.org/10.1200/ JCO.2007.14.4147. [PubMed]

7. Gewirtz DA. A critical evaluation of the mechanisms of action proposed for the antitumor effects of the anthracycline antibiotics adriamycin and daunorubicin. Biochem Pharmacol. 1999; 57:727-41. https://doi. org/10.1016/s0006-2952(98)00307-4. [PubMed] 
8. Plasilova ML, Hayse B, Killelea BK, Horowitz NR, Chagpar AB, Lannin DR. Features of triple-negative breast cancer: Analysis of 38,813 cases from the national cancer database. Medicine (Baltimore). 2016; 95:e4614. https:// doi.org/10.1097/MD.0000000000004614. [PubMed]

9. Weaver BA. How Taxol/paclitaxel kills cancer cells. Mol Biol Cell. 2014; 25:2677-81. https://doi.org/10.1091/mbc. E14-04-0916. [PubMed]

10. Marty M, Extra JM, Giacchetti S, Cuvier C, Espie M. Taxoids: a new class of cytotoxic agents. Nouv Rev Fr Hematol. 1994; 36:S25-28. [PubMed]

11. Schiff PB, Horwitz SB. Taxol stabilizes microtubules in mouse fibroblast cells. Proc Natl Acad Sci U S A. 1980; 77:1561-65. https://doi.org/10.1073/pnas.77.3.1561. [PubMed]

12. Lara-Gonzalez P, Westhorpe FG, Taylor SS. The spindle assembly checkpoint. Curr Biol. 2012; 22:R966-80. https:// doi.org/10.1016/j.cub.2012.10.006. [PubMed]

13. Michaud LB, Valero V, Hortobagyi G. Risks and benefits of taxanes in breast and ovarian cancer. Drug Saf. 2000; 23:401-28. https://doi.org/10.2165/00002018-20002305000005. [PubMed]

14. Giatromanolaki A, Sivridis E, Fiska A, Koukourakis MI. The CD44+/CD24-phenotype relates to 'triple-negative' state and unfavorable prognosis in breast cancer patients. Med Oncol. 2011; 28:745-52. https://doi.org/10.1007/ s12032-010-9530-3. [PubMed]

15. Sawin KE, LeGuellec K, Philippe M, Mitchison TJ. Mitotic spindle organization by a plus-end-directed microtubule motor. Nature. 1992; 359:540-43. https://doi. org/10.1038/359540a0. [PubMed]

16. Gaglio T, Saredi A, Bingham JB, Hasbani MJ, Gill SR, Schroer TA, Compton DA. Opposing motor activities are required for the organization of the mammalian mitotic spindle pole. J Cell Biol. 1996; 135:399-414. https://doi. org/10.1083/jcb.135.2.399. [PubMed]

17. Liu X, Gong H, Huang K. Oncogenic role of kinesin proteins and targeting kinesin therapy. Cancer Sci. 2013; 104:651-56. https://doi.org/10.1111/cas.12138. [PubMed]

18. Jin Q, Huang F, Wang X, Zhu H, Xian Y, Li J, Zhang S, Ni Q. High Eg5 expression predicts poor prognosis in breast cancer. Oncotarget. 2017; 8:62208-16. https://doi. org/10.18632/oncotarget.19215. [PubMed]

19. Liu C, Zhou N, Li J, Kong J, Guan X, Wang X. Eg5 Overexpression Is Predictive of Poor Prognosis in Hepatocellular Carcinoma Patients. Dis Markers. 2017; 2017:2176460. https://doi.org/10.1155/2017/2176460. [PubMed]

20. Lu M, Zhu H, Wang X, Zhang D, Xiong L, Xu L, You Y. The prognostic role of Eg5 expression in laryngeal squamous cell carcinoma. Pathology. 2016; 48:214-18. https://doi.org/10.1016/j.pathol.2016.02.008. [PubMed]

21. Liu L, Liu X, Mare M, Dumont AS, Zhang H, Yan D, Xiong Z. Overexpression of Eg5 correlates with high grade astrocytic neoplasm. J Neurooncol. 2016; 126:77-80. https://doi.org/10.1007/s11060-015-1954-3. [ [PubMed]

22. Sun D, Lu J, Ding K, Bi D, Niu Z, Cao Q, Zhang J, Ding S. The expression of $\mathrm{Eg} 5$ predicts a poor outcome for patients with renal cell carcinoma. Med Oncol. 2013; 30:476. https://doi.org/10.1007/s12032-013-0476-0. [․ㅏbMed]

23. Castillo A, Morse HC 3rd, Godfrey VL, Naeem R, Justice MJ. Overexpression of Eg5 causes genomic instability and tumor formation in mice. Cancer Res. 2007; 67:1013847. https://doi.org/10.1158/0008-5472.CAN-07-0326. [PubMed]

24. Infante JR, Patnaik A, Verschraegen CF, Olszanski AJ, Shaheen M, Burris HA, Tolcher AW, Papadopoulos KP, Beeram M, Hynes SM, Leohr J, Lin AB, Li LQ, et al. Two Phase 1 dose-escalation studies exploring multiple regimens of litronesib (LY2523355), an Eg5 inhibitor, in patients with advanced cancer. Cancer Chemother Pharmacol. 2017; 79:315-26. https://doi.org/10.1007/s00280-016-3205-5. [PubMed]

25. Komlodi-Pasztor E, Sackett DL, Fojo AT. Inhibitors targeting mitosis: tales of how great drugs against a promising target were brought down by a flawed rationale. Clin Cancer Res. 2012; 18:51-63. https://doi. org/10.1158/1078-0432.CCR-11-0999. [PubMed]

26. Guido BC, Ramos LM, Nolasco DO, Nobrega CC, Andrade BY, Pic-Taylor A, Neto BA, Corrêa JR. Impact of kinesin Eg5 inhibition by 3,4-dihydropyrimidin-2(1H)one derivatives on various breast cancer cell features. BMC Cancer. 2015; 15:283. https://doi.org/10.1186/s12885-0151274-1. [PubMed]

27. Ramos LM, Guido BC, Nobrega CC, Corrêa JR, Silva RG, de Oliveira HC, Gomes AF, Gozzo FC, Neto BA. The Biginelli reaction with an imidazolium-tagged recyclable iron catalyst: kinetics, mechanism, and antitumoral activity. Chemistry. 2013; 19:4156-68. https://doi.org/10.1002/ chem.201204314. [PubMed]

28. Choe MH, Kim J, Ahn J, Hwang SG, Oh JS, Kim JS. Centrosome Clustering Is a Tumor-selective Target for the Improvement of Radiotherapy in Breast Cancer Cells. Anticancer Res. 2018; 38:3393-400. https://doi. org/10.21873/anticanres.12606. [PubMed]

29. Charafe-Jauffret E, Ginestier C, Iovino F, Tarpin C, Diebel M, Esterni B, Houvenaeghel G, Extra JM, Bertucci F, Jacquemier J, Xerri L, Dontu G, Stassi G, et al. Aldehyde dehydrogenase 1-positive cancer stem cells mediate metastasis and poor clinical outcome in inflammatory breast cancer. Clin Cancer Res. 2010; 16:45-55. https://doi. org/10.1158/1078-0432.CCR-09-1630. [PubMed]

30. Charafe-Jauffret E, Ginestier C, Iovino F, Wicinski J, Cervera N, Finetti P, Hur MH, Diebel ME, Monville F, Dutcher J, Brown M, Viens P, Xerri L, et al. Breast cancer cell lines contain functional cancer stem cells with metastatic capacity and a distinct molecular signature. Cancer Res. 2009; 69:1302-13. https://doi. org/10.1158/0008-5472.CAN-08-2741. [PubMed] 
31. Ginestier C, Hur MH, Charafe-Jauffret E, Monville F, Dutcher J, Brown M, Jacquemier J, Viens P, Kleer CG, Liu S, Schott A, Hayes D, Birnbaum D, et al. ALDH1 is a marker of normal and malignant human mammary stem cells and a predictor of poor clinical outcome. Cell Stem Cell. 2007; 1:555-67. https://doi.org/10.1016/j. stem.2007.08.014. [PubMed]

32. Zhong Y, Lin Y, Shen S, Zhou Y, Mao F, Guan J, Sun Q. Expression of ALDH1 in breast invasive ductal carcinoma: an independent predictor of early tumor relapse. Cancer Cell Int. 2013; 13:60. https://doi.org/10.1186/1475-286713-60. [PubMed]

33. Kida K, Ishikawa T, Yamada A, Shimada K, Narui K, Sugae S, Shimizu D, Tanabe M, Sasaki T, Ichikawa Y, Endo I. Effect of ALDH1 on prognosis and chemoresistance by breast cancer subtype. Breast Cancer Res Treat. 2016; 156:261-69. https://doi.org/10.1007/s10549-016-3738-7. [PubMed]

34. Kang EJ, Jung H, Woo OH, Park KH, Woo SU, Yang DS, Kim AR, Lee JB, Kim YH, Kim JS, Seo JH. Association of aldehyde dehydrogenase 1 expression and biologically aggressive features in breast cancer. Neoplasma. 2014; 61:352-62. https://doi.org/10.4149/neo_2014_045. [PubMed]

35. Miyoshi Y, Shien T, Ogiya A, Ishida N, Yamazaki K, Horii R, Horimoto Y, Masuda N, Yasojima H, Inao T, Osako T, Takahashi M, Tomioka N, et al, and Collaborative Study Group of Scientific Research of the Japanese Breast Cancer Society. Differences in expression of the cancer stem cell marker aldehyde dehydrogenase 1 among estrogen receptor-positive/human epidermal growth factor receptor type 2-negative breast cancer cases with early, late, and no recurrence. Breast Cancer Res. 2016; 18:73. https://doi. org/10.1186/s13058-016-0731-3. [PubMed]

36. Pei YY, Li GC, Ran J, Wan XH, Wei FX, Wang L. Kinesin Family Member 11 Enhances the Self-Renewal Ability of Breast Cancer Cells by Participating in the Wnt/ $\beta$-Catenin Pathway. J Breast Cancer. 2019; 22:522-32. https://doi. org/10.4048/jbc.2019.22.e51. [PubMed]

37. Rowinsky EK, Chaudhry V, Cornblath DR, Donehower RC. Neurotoxicity of Taxol. J Natl Cancer Inst Monogr. 1993; 15:107-15. [PubMed]

38. Nakai R, Iida S, Takahashi T, Tsujita T, Okamoto S, Takada C, Akasaka K, Ichikawa S, Ishida H, Kusaka H, Akinaga S, Murakata C, Honda S, et al. K858, a novel inhibitor of mitotic kinesin $\mathrm{Eg} 5$ and antitumor agent, induces cell death in cancer cells. Cancer Res. 2009; 69:3901-09. https://doi. org/10.1158/0008-5472.CAN-08-4373. [PubMed]

39. Ding S, Xing N, Lu J, Zhang H, Nishizawa K, Liu S, Yuan X, Qin Y, Liu Y, Ogawa O, Nishiyama H. Overexpression of Eg5 predicts unfavorable prognosis in non-muscle invasive bladder urothelial carcinoma. Int J Urol. 2011; 18:43238. https://doi.org/10.1111/j.1442-2042.2011.02751.x. [PubMed]

40. Exertier P, Javerzat S, Wang B, Franco M, Herbert J, Platonova N, Winandy M, Pujol N, Nivelles O, Ormenese
S, Godard V, Becker J, Bicknell R, et al. Impaired angiogenesis and tumor development by inhibition of the mitotic kinesin Eg5. Oncotarget. 2013; 4:2302-16. https:// doi.org/10.18632/oncotarget.1490. [PubMed]

41. Talapatra SK, Anthony NG, Mackay SP, Kozielski F. Mitotic kinesin Eg5 overcomes inhibition to the phase I/ II clinical candidate SB743921 by an allosteric resistance mechanism. J Med Chem. 2013; 56:6317-29. https://doi. org/10.1021/jm4006274. [PubMed]

42. Myers SM, Collins I. Recent findings and future directions for interpolar mitotic kinesin inhibitors in cancer therapy. Future Med Chem. 2016; 8:463-89. https://doi.org/10.4155/ fmc.16.5. [PubMed]

43. Venere M, Horbinski C, Crish JF, Jin X, Vasanji A, Major J, Burrows AC, Chang C, Prokop J, Wu Q, Sims PA, Canoll P, Summers MK, et al. The mitotic kinesin KIF11 is a driver of invasion, proliferation, and self-renewal in glioblastoma. Sci Transl Med. 2015; 7:304ra143. https://doi.org/10.1126/ scitranslmed.aac6762. [PubMed]

44. Khoury HJ, Garcia-Manero G, Borthakur G, Kadia T, Foudray MC, Arellano M, Langston A, Bethelmie-Bryan B, Rush S, Litwiler K, Karan S, Simmons H, Marcus AI, et al. A phase 1 dose-escalation study of ARRY-520, a kinesin spindle protein inhibitor, in patients with advanced myeloid leukemias. Cancer. 2012; 118:3556-64. https://doi. org/10.1002/cncr.26664. [PubMed]

45. Lucanus AJ, Yip GW. Kinesin superfamily: roles in breast cancer, patient prognosis and therapeutics. Oncogene. 2018; 37:833-38. https://doi.org/10.1038/onc.2017.406. [PubMed]

46. De Iuliis F, Taglieri L, Salerno G, Giuffrida A, Milana B, Giantulli S, Carradori S, Silvestri I, Scarpa S. The kinesin Eg5 inhibitor K858 induces apoptosis but also survivinrelated chemoresistance in breast cancer cells. Invest New Drugs. 2016; 34:399-406. https://doi.org/10.1007/s10637016-0345-8. [PubMed]

47. Sakowicz R, Finer JT, Beraud C, Crompton A, Lewis E, Fritsch A, Lee Y, Mak J, Moody R, Turincio R, Chabala JC, Gonzales P, Roth S, et al. Antitumor activity of a kinesin inhibitor. Cancer Res. 2004; 64:3276-80. https://doi. org/10.1158/0008-5472.can-03-3839. [PubMed]

48. Gomez HL, Philco M, Pimentel P, Kiyan M, Monsalvo ML, Conlan MG, Saikali KG, Chen MM, Seroogy JJ, Wolff AA, Escandon RD. Phase I dose-escalation and pharmacokinetic study of ispinesib, a kinesin spindle protein inhibitor, administered on days 1 and 15 of a 28-day schedule in patients with no prior treatment for advanced breast cancer. Anticancer Drugs. 2012; 23:335-41. https:// doi.org/10.1097/CAD.0b013e32834e74d6. [PubMed]

49. Knox JJ, Gill S, Synold TW, Biagi JJ, Major P, Feld R, Cripps C, Wainman N, Eisenhauer E, Seymour L. A phase II and pharmacokinetic study of SB-715992, in patients with metastatic hepatocellular carcinoma: a study of the National Cancer Institute of Canada Clinical Trials Group (NCIC CTG IND.168). Invest New Drugs. 2008; 
26:265-72. https://doi.org/10.1007/s10637-007-9103-2. [PubMed]

50. Purcell JW, Davis J, Reddy M, Martin S, Samayoa K, Vo H, Thomsen K, Bean P, Kuo WL, Ziyad S, Billig J, Feiler HS, Gray JW, et al. Activity of the kinesin spindle protein inhibitor ispinesib (SB-715992) in models of breast cancer. Clin Cancer Res. 2010; 16:566-76. https://doi. org/10.1158/1078-0432.CCR-09-1498. [PubMed]

51. Wang Y, Wu X, Du M, Chen X, Ning X, Chen H, Wang S, Liu J, Liu Z, Li R, Fu G, Wang C, McNutt MA, et al. Eg5 inhibitor YL001 induces mitotic arrest and inhibits tumor proliferation. Oncotarget. 2017; 8:42510-24. https://doi. org/10.18632/oncotarget.17207. [PubMed]

52. Remon J, Abedallaa N, Taranchon-Clermont E, Bluthgen V, Lindsay CR, Besse B, Thomas de Montpréville V. CD52, CD22, CD26, EG5 and IGF-1R expression in thymic malignancies. Lung Cancer. 2017; 108:168-72. https://doi. org/10.1016/j.lungcan.2017.03.019. [PubMed]

53. Jiang M, Zhuang H, Xia R, Gan L, Wu Y, Ma J, Sun Y, Zhuang Z. KIF11 is required for proliferation and selfrenewal of docetaxel resistant triple negative breast cancer cells. Oncotarget. 2017; 8:92106-18. https://doi. org/10.18632/oncotarget.20785. [PubMed]

54. Endl E, Gerdes J. The Ki-67 protein: fascinating forms and an unknown function. Exp Cell Res. 2000; 257:231-37. https://doi.org/10.1006/excr.2000.4888. [PubMed]

55. Sobecki M, Mrouj K, Colinge J, Gerbe F, Jay P, Krasinska L, Dulic V, Fisher D. Cell-Cycle Regulation Accounts for Variability in Ki-67 Expression Levels. Cancer Res. 2017; 77:2722-34. https://doi.org/10.1158/0008-5472.CAN-160707. [PubMed]
56. Althobiti M, El Ansari R, Aleskandarany M, Joseph C, Toss MS, Green AR, Rakha EA. The prognostic significance of ALDH1A1 expression in early invasive breast cancer. Histopathology. 2020; 77:437-48. https://doi.org/10.1111/ his.14129. [PubMed]

57. Imai T, Oue N, Sentani K, Sakamoto N, Uraoka N, Egi H, Hinoi T, Ohdan H, Yoshida K, Yasui W. KIF11 Is Required for Spheroid Formation by Oesophageal and Colorectal Cancer Cells. Anticancer Res. 2017; 37:47-55. https://doi. org/10.21873/anticanres.11287. [PubMed]

58. Kastan MB, Schlaffer E, Russo JE, Colvin OM, Civin CI, Hilton J. Direct demonstration of elevated aldehyde dehydrogenase in human hematopoietic progenitor cells. Blood. 1990; 75:1947-50. [PubMed]

59. Moreb J, Zucali JR, Zhang Y, Colvin MO, Gross MA. Role of aldehyde dehydrogenase in the protection of hematopoietic progenitor cells from 4-hydroperoxycyclophosphamide by interleukin 1 beta and tumor necrosis factor. Cancer Res. 1992; 52:1770-74. [PubMed]

60. Liu M, Yu H, Huo L, Liu J, Li M, Zhou J. Validating the mitotic kinesin $\mathrm{Eg} 5$ as a therapeutic target in pancreatic cancer cells and tumor xenografts using a specific inhibitor. Biochem Pharmacol. 2008; 76:169-78. https://doi. org/10.1016/j.bcp.2008.04.018. [PubMed] 